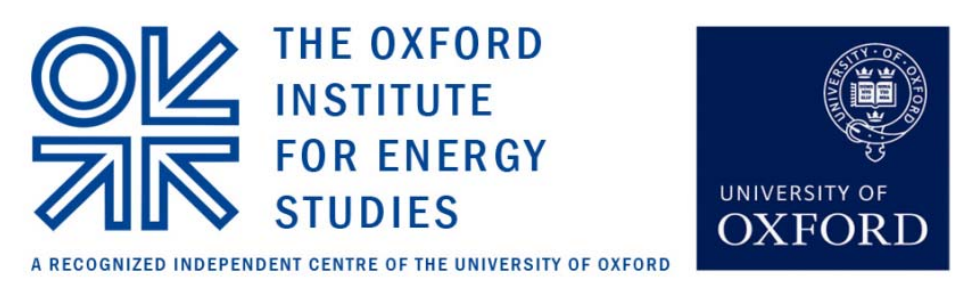

\title{
The Potential Impact of \\ North American LNG Exports
}

\author{
James Henderson
}

NG 68

October 2012 
The contents of this paper are the author's sole responsibility. They do not necessarily represent the views of the Oxford Institute for Energy Studies, of any of the Institute's members, and/or of the author's other affiliations.

Copyright (C) 2012

\section{Oxford Institute for Energy Studies}

(Registered Charity, No. 286084)

This publication may be reproduced in part for educational or non-profit purposes without special permission from the copyright holder, provided acknowledgment of the source is made. No use of this publication may be made for resale or for any other commercial purpose whatsoever without prior permission in writing from the Oxford Institute for Energy Studies.

ISBN 978-1-907555-59-6 


\section{Acknowledgements}

I would like to thank my colleagues at the OIES for their help with this research. In particular I am very grateful for the support and comments provided by Howard Rogers and David Ledesma, whose contributions were all vital to the completion of my analysis. I would also like to thank my editor, John Elkins, for his detailed corrections and useful comments.

I would also like to acknowledge the contribution of my colleagues at Lambert Energy Advisory, who as always have been generous with their time and support.

Thanks also to the many industry executives, consultants and analysts with whom I have discussed this topic, but as always the results of the analysis remain entirely my responsibility. 


\section{Preface}

Expectations that the world's three major regional gas markets would become ever more closely linked via flexible LNG supply were put 'on hold' with the emergence of the US shale phenomenon from circa 2008 onwards as North America, requiring minimal LNG imports, effectively de-linked from the rest of the gas world. At present the divergence in price between the US Henry Hub, European hub or oil-indexed prices and Asian LNG JCC contract prices has never been so marked. However, just as 'nature abhors a vacuum', trade and arbitrage dynamics will inevitably seek to exploit such price differences and, in doing so, reduce them. Beyond 2015, new sources of LNG supply from Australia, North America and East Africa will accelerate such arbitrage activity, although the scale and timing of these new ‘waves’ of LNG are subject to considerable uncertainty.

This paper by James Henderson focuses on future North American LNG exports which, while subject to political and production performance uncertainty, have the potential to create considerable impact in the likely destination markets of Asia, and also (through displacement of other Middle East or African - sourced LNG) Europe. Whilst it is unlikely that all the identified US and Canadian LNG export projects will proceed, there is the potential that sufficient investment will be forthcoming to allow arbitrage to proceed to its 'equilibrium', given favourable policy decisions.

The paper provides a timely summary of the of investment intentions, policy options and consequences, the extent to which the prospect of LNG exports are stimulating a desire to move to a hub-based price formation mechanism in Asia and the consequent dilemmas facing LNG suppliers (and would-be suppliers) who have a strong preference for JCC-based pricing. For observers of the increasingly inter-linked global gas scene and those who are interested in the evolution of gas pricing mechanisms, this paper provides an informative and comprehensive description of the 'state of play' of this potentially game-changing development.

Howard Rogers 


\section{Contents}

Acknowledgements ............................................................................................................................. iii

1. Introduction ................................................................................................................................... 1

2. The Commercial Logic for Gas Exports from North America .............................................. 4

3. Potential North American Export Projects.............................................................................. 9

Canada's gas resources................................................................................................................. 9

Key export projects in western Canada .............................................................................................. 10

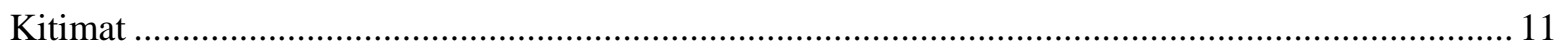

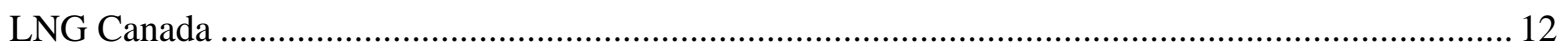

Lelu Island (Petronas/Progress Energy).................................................................................... 13

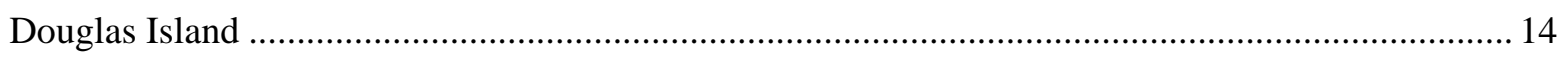

Conclusions on Canadian LNG projects................................................................................. 14

Potential US gas export projects...................................................................................................... 16

Cheniere Energy is leading the way at Sabine Pass ...................................................................... 17

Cheniere's second export project at Corpus Christi is at a much earlier stage .................................... 20

Seven more LNG export projects have already been proposed to the FERC ………………………... 20

Other possible export projects.......................................................................................................... 24

Conclusions on North American LNG export facilities............................................................ 25

4. The Political Debate over LNG Exports.................................................................................... 28

Canada keen to replace pipeline exports to the US with LNG exports to Asia ................................... 28

US struggling to balance economic and trade incentives with domestic price and environmental concerns ……………………………………………………………………………..... 30

5. How Significant will North American LNG Exports be in the Global Gas Market? ... 39

The theoretical impact of the elasticity of gas supply in the US and Asia.......................................... 40

The potential impact of US gas exports on global gas price formation ................................................ 51

6. Overall Conclusions................................................................................................................... 56

Bibliography .............................................................................................................................. 58 


\section{Figures}

Figure 1: The contrasting trend in import requirements in the US and Asia-Pacific ...............5

Figure 2: Gas Prices in the US, Japan and Europe since 2007 ..........................................6

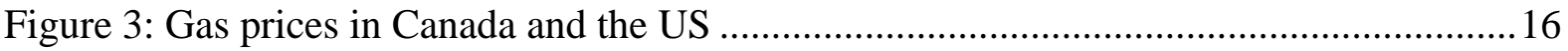

Figure 4: Canadian Gas Production and Net Exports (to US), 2007-2011 .............................29

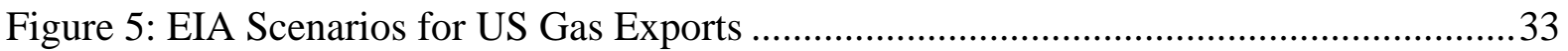

Figure 6: Price Impact of Exports on EIA Reference Case Gas Price....................................33

Figure 7: Difference in gas price relative to Reference Case under different gas export

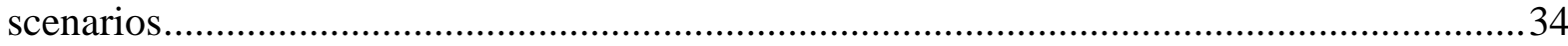

Figure 8: The Impact of Different Shale Gas Production Scenarios on US gas prices ...........35

Figure 9: The Impact of Elasticity on Prices in Domestic and Foreign Markets assuming Import/Export Trade

Figure 10: The Potential Impact of the Relative Elasticity of Supply on Prices in Domestic and Foreign Markets

Figure 11: Cost of Supply Curve for US Shale Gas

Figure 12: The Cost of US LNG Exports Arriving in Europe (based on various Henry Hub

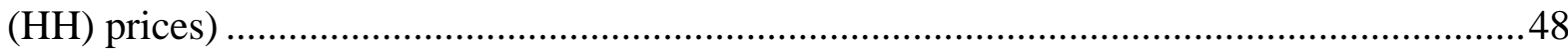

Figure 13: Estimated Cost of LNG supply to Asia .............................................................49

\section{Tables}

Table 1: Canadian Gas Resources by Province .................................................................... 10

Table 2: Proposed and Potential LNG Export Projects in North America ..............................25

Table 3: The Delivered Cost of US LNG Exports to Europe and Asia (\$/mmbtu) .................46

Table 4: Potential Reaction of Market Participants to US gas export possibilities ..................51

Table 5: Existing agreements for the export of North American gas .....................................53

Table 6: Asian owners of North American gas assets ...........................................................54

\section{Maps}

Map 1: North American LNG Projects 


\section{Introduction}

The position of North America ${ }^{1}$ within the global gas market has been a divergent one over the past two decades. From a state of relative self-sufficiency in the early 1990s (albeit with significant cross-border trade between the three countries in the region, especially exports from Canada to the US), the continent increasingly became an importer of gas during the 2000s as US production in particular started to go into decline. ${ }^{2}$ Indeed by 2004 the US appeared set to become a major growth market for imported LNG and by March 2006 five regasification terminals had been constructed in North America, seventeen had been approved by government regulators and a further twenty-five were on file pending the approval process. In addition twenty-one other projects were being planned to give a total potential import capacity of over $700 \mathrm{bcma}^{3}$ While demand for imports in North America was never likely to require all this capacity to be built, even in the most pessimistic outlook for indigenous production, in reality the remarkable turnaround in US gas production since 2005, driven by the emergence of shale gas, has rendered any import facilities that were built effectively redundant. ${ }^{4}$ Indeed by 2011 the North American region had again become selfsufficient in gas and the prospect of significant LNG exports from both the US and Canada now has the potential to transform the dynamics of the global gas market.

The importance of this change in the North American position from gas importer to exporter was highlighted by Rogers $(2012)^{5}$ in his analysis of the increasing connectivity and price linkage between regions in the global gas market, driven in particular by the growing availability of LNG. As the title of his paper highlights, the potential for LNG exports from North America is one of the key variables in the matrix of an increasingly globalised gas supply and demand picture, although it will clearly interact with a number of other fundamental drivers as the dynamics of a new model for gas supply and pricing emerge. The second key variable identified by Rogers is Asian gas demand: rapid growth in Chinese gas consumption, combined with the surge in Japanese LNG demand after the Fukushima nuclear disaster, has highlighted the short and long-term growth possibilities for gas in the Far East. Indeed the surge in demand in the Asia-Pacific over the past 4 years (rising by $6.5 \%$ per

\footnotetext{
${ }^{1}$ North America defined as the US, Canada and Mexico, as in the BP Statistical Review of World Energy 2012

${ }^{2}$ BP (2012)

${ }^{3}$ Data sourced from http://intelligencepress.com/features/lng/, "North American LNG Import Terminals”, accessed $5^{\text {th }}$ Sept 2012

${ }^{4}$ Some existing import terminals served parts of the US East Coast which are poorly served by pipeline gas transmission networks.

${ }^{5}$ Rogers (2012).
} 
annum in the period 2007-2011), ${ }^{6}$ combined with a slow-down in the growth of new LNG supply due to the reductions in investment by producers during the 2008-09 global financial crisis, has caused the price imbalances that are now encouraging US and Canadian companies to explore the opportunity for export sales.

With US spot gas prices falling to a level of \$2-3/mmbtu in the first half of 2012 (and even briefly dipping below $\$ 2 / \mathrm{mmbtu}$ in April 2012) compared to European long-term contract prices of around $\$ 12 / \mathrm{mmbtu}$ and Asian spot LNG prices close to $\$ 18 / \mathrm{mmbtu}$, it is obvious that an arbitrage opportunity exists for North American producers who can construct or gain access to new liquefaction facilities. As this working paper will outline, two such plants (one in Canada and one in the US) have already been fully approved by the regulatory authorities while many more are proceeding through the approval process or are in the planning stage. However, as Rogers also points out, potential North American exports are only one element of the emerging global gas model. New supply from Australia, East Africa, the Mediterranean and the Asian region itself will take their place on the supply curve into which North American LNG will also fit, while the role of Russia as a potential swing supplier to both Europe and potentially Asia will also be crucial as its decisions on the optimal balance of export volumes versus price realisation will play a significant role in framing the opportunity for new exporters. Furthermore, gas demand in both Asia and Europe could vary dramatically depending upon commercial and economic performance and on political decision-making, creating further uncertainty for potential gas exporters. Finally the level of oil prices will also be important given that the majority of contracts in Asia and Europe contain gas prices that are partially or entirely linked to the price of crude or a basket of crude and oil products.

Despite these uncertainties, however, it is now clear that the future of North American gas exports will have a role in determining the shape of the global gas market over the next decade. It is possible that this role could be very limited if political concerns in the US over the possibility of rising internal US gas prices, security of supply issues or environmental objections over drilling for unconventional gas hold sway. In this instance, or if the performance of the country's shale gas resource disappoints, then the opportunity for alternative suppliers to Europe and Asia will be enhanced. Alternatively, if free market principles are allowed to take precedence and North American unconventional gas output

\footnotetext{
${ }^{6} \mathrm{BP}(2012)$
} 
continues to grow then LNG exports from Canada and the US could become a major new source of global supply from as early as 2015, at a time when many other new projects will also be close to first gas.

This paper seeks to deepen the analysis of the potential impact of North American gas exports initiated by Rogers ${ }^{7}$ by assessing the latest political and commercial developments surrounding potential liquefaction projects in both the US and Canada and their potential impact on both the domestic North American and the global LNG markets. Section 2 describes the commercial logic for gas exports from North America in more detail, highlighting the differing trends in the US, European and Asian markets. Section 3 then describes the potential export projects that have been approved, are awaiting approval or are being planned in Canada and the US and assesses the potential capacity for LNG exports from the region. Section 4 then analyses the political debate surrounding the potential impact of gas exports, and highlights the differing views currently being taken by the US and Canadian authorities. Section 5 then discusses the potential impact of North American LNG exports on the global gas market, analysing the interaction of supply, demand and prices across the major gas producing and consuming regions as well as the contrasting impact of different investors in the US and Canadian gas sectors. Section 6 then provides conclusions and suggests that although the volumes of exports leaving Canada and the US may ultimately not be as large as currently envisaged, their impact on the formation of gas prices in the global market may still be significant.

\footnotetext{
${ }^{7}$ Rogers (2012)
} 


\section{The Commercial Logic for Gas Exports from North America}

The announcement in October 2011 of the US LNG export deal between Cheniere Energy and BG Group, ${ }^{8}$ and Cheniere’s subsequent agreements with Kogas, Gas Natural and GAIL (plus a second contract for additional volumes with BG Group), have moved the issue of possible gas exports from the US out of the realms of theory and made them a practical likelihood, with significant potential implications for the global gas market. The commercial incentive to export gas from North America, and especially from the US, has been created by the differing trajectories of the global gas markets over the past 5-10 years, in particular the contrast between the US domestic market and the gas market in the Asia-Pacific region. After a 6\% decline in production from 2000 to 2005, the US gas market appeared to be heading for an ever larger supply/demand imbalance that would require increasing imports of pipeline gas from Canada and LNG from the global market. However, the picture has changed radically over the past five to six years as the "shale gas revolution" has led to a $27 \%$ increase in gas production, a sharp fall in gas imports from Canada and a complete reversal of strategy for the many companies that had built LNG import terminals in the mid-2000s. Indeed the US' gas import requirement has fallen by $65 \%$ since 2005 , and it now appears very likely that the country could be self-sufficient in gas well before the end of the current decade. ${ }^{9}$

In contrast the Asia-Pacific market has become ever more import dependent as, despite a 76\% increase in its domestic gas production between 2000 and 2011, consumption has more than doubled over the same period, meaning that the region's need for gas imports has increased by almost $500 \%$ from $19 \mathrm{bcm}$ to $112 \mathrm{bcm}$. Figure 1 shows the differing trends in the two regions, emphasizing that while the US is now able to supply most of its own gas needs, the Asia-Pacific region has become increasingly reliant on imported gas, mainly in the form of LNG.

\footnotetext{
${ }^{8}$ Reuters, 26 Oct 2011, “Cheniere and BG ink \$8bn deal to export US LNG”.

${ }^{9}$ Data based on calculations from BP 2012.
} 
Figure 1: The contrasting trend in import requirements in the US and Asia-Pacific

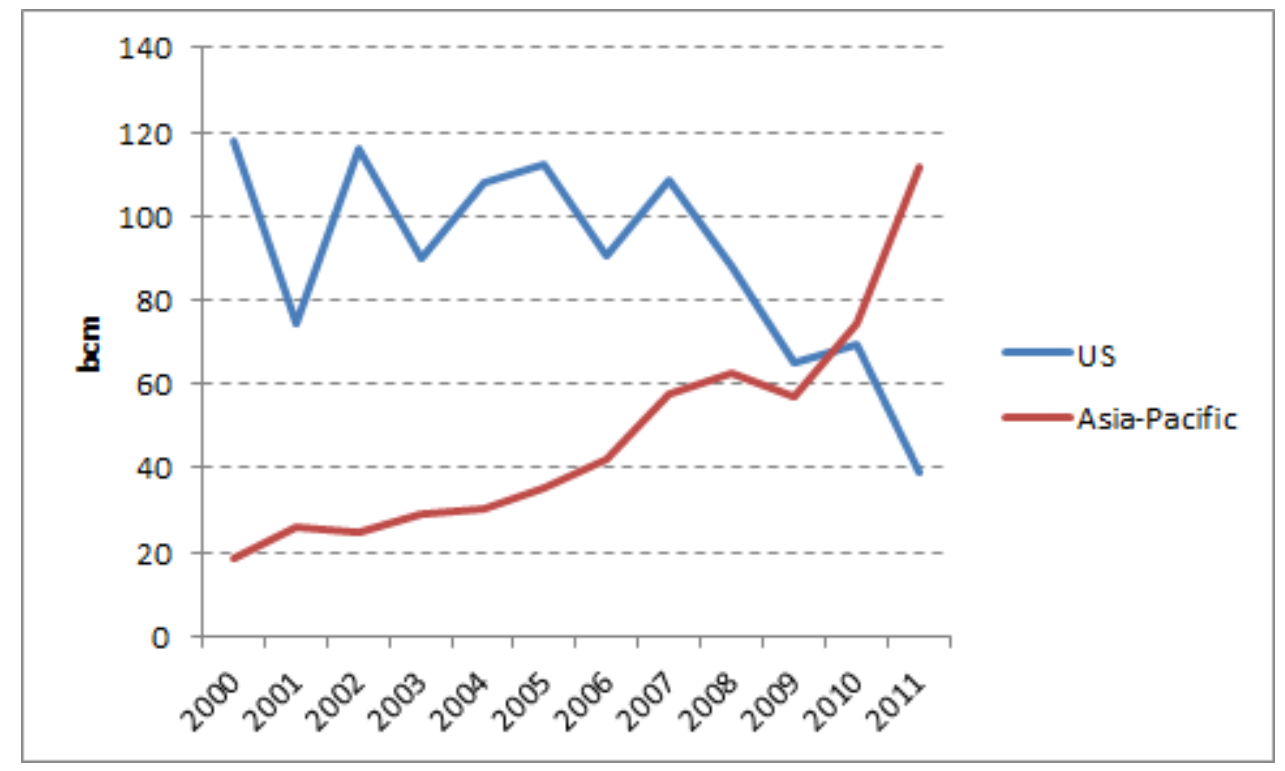

Source: Data from BP (2012)

This supply/demand trend has been reflected in gas prices in the two regions, with the benchmark Henry Hub gas price falling to an average of only $\$ 2.36 / \mathrm{mmbtu}$ in the first half of 2012 while average prices for LNG in Japan (Asia’s largest LNG importer) have peaked at over $\$ 17 / \mathrm{mmbtu}^{10}$ As Figure 2 demonstrates, these 2012 prices reflect a trend that has been emerging over the past four years since mid-2008, when the impact of shale gas in the US, combined with the economic downturn that led to a slackening of gas demand growth, first caused an imbalance of supply and demand in the North American gas market.

${ }^{10}$ Data sourced from Energy Intelligence Group price database 
Figure 2: Gas Prices in the US, Japan and Europe since 2007

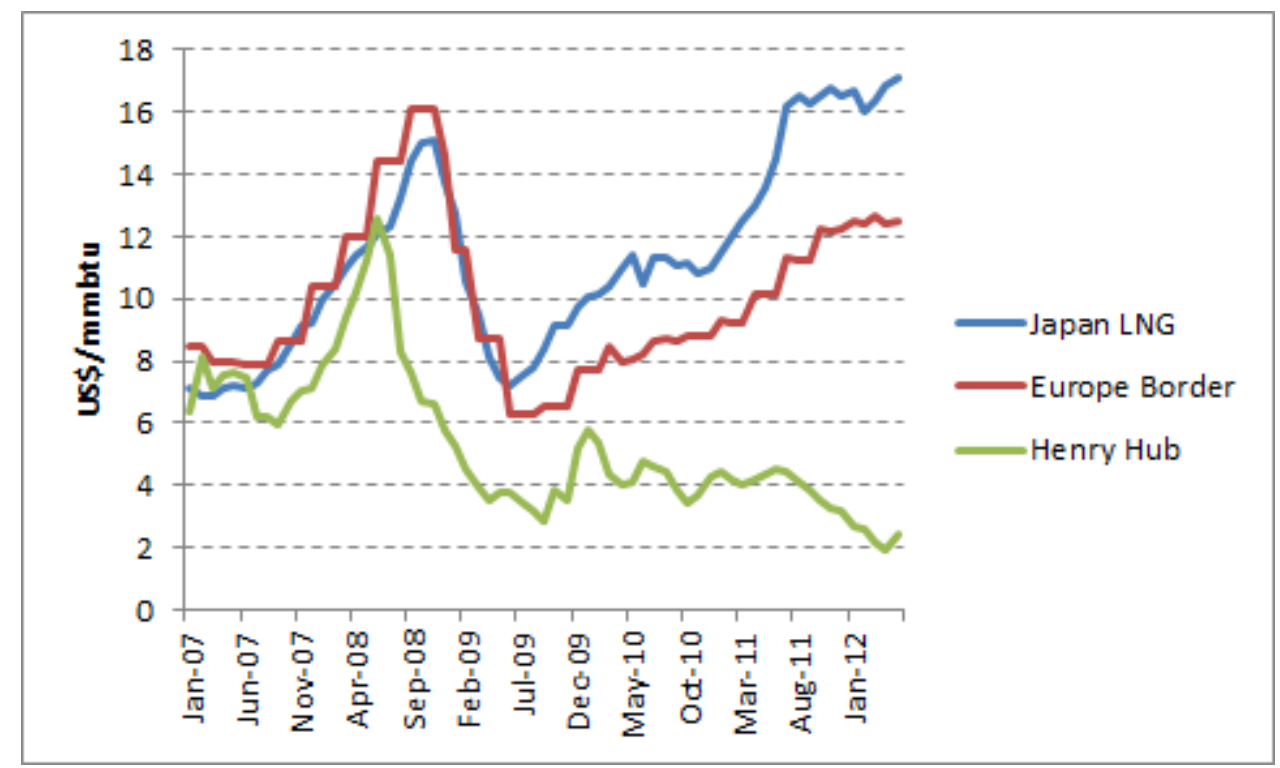

Source: Data from Energy Intelligence Group

Another key factor that has caused the difference in price trends between Asia and the US, and which also explains the European gas price shown in Figure 2, is the fact that gas prices in both the non-US regions are largely set in relation to oil prices. Since the 1970s LNG contracts in Asia have been set relative to crude oil, mainly in the form of the Japan Customscleared Crude (JCC) price, while in Europe the majority of long-term contracts have been set relative to a basket of energy products that has included a large proportion of fuel oil and oil product prices. As a result the long-term contract price for gas in both regions has risen sharply over the past five years in line with an oil price that has increased by more than $50 \%$ to average over $\$ 110$ per barrel in 2011. ${ }^{11}$ Meanwhile prices in the US, driven by gas-on-gas competition in an increasingly well supplied market, have fallen from a high of over $\$ 12 /$ mmbtu in early 2008 to a low of below \$2/mmbtu in April 2012. ${ }^{12}$

Given the changing price dynamics of these three markets, which make up 70\% of global gas consumption outside Russia, ${ }^{13}$ it is not surprising that a number of US companies have announced plans to convert LNG import terminals into export facilities. Furthermore, Canada is also set to join the North American gas export game as it has discovered its own shale resources and is looking to replace the decline in its pipeline exports to the US. In the case of the brownfield conversion projects in the US the margins to be made from the sale of North

\footnotetext{
${ }^{11} \mathrm{BP}(2012)$

${ }^{12}$ Data sourced from Energy Intelligence Group database

${ }^{13}$ Calculation based on data from BP 2012
} 
American LNG into Europe and especially Asia are very significant at current prices, even after the costs of liquefaction and transport are added, and the fact that gas could be exported from a region where prices are set by gas market forces into regions where they are largely set in relation to oil prices raises a number of key issues, all of which are inter-linked. The Canadian greenfield projects have somewhat different economics given their higher initial capital costs, but the shorter transport distance to the Asian market means that they could also provide a very competitive new source of LNG supply.

The first key issue, though, relates to the extent to which US exports will occur. The answer to this, as discussed in the analysis below, will depend upon a number of inter-related factors including the results from the continuing development of the country's unconventional and conventional gas resources, levels of US gas consumption, the impact of both on gas prices and political perceptions of the impact of gas exports on energy security and prices. At present the debate has been extended until beyond the US presidential elections in November 2012, but in 2013 key decisions will need to be taken about the granting of export licences to a number of projects which will indicate whether the US Administration is set to follow free market principles or is more concerned about protecting US consumers from the risk of higher gas prices.

The second issue is the level and timing of exports from Canada. Political and commercial forces appear to be aligned behind a strategy of greater commercial co-operation with Asia, with energy exports playing a key role in achieving this objective. However, as mentioned above, the capital costs of these greenfield projects may demand a higher gas price than that acceptable for US brownfield projects, meaning that the questions concerning how many Canadian export projects will be completed and when they could start will be related both to the availability of gas resources and the price formation mechanism that is used in any sales contracts. In other words it is possible some Canadian suppliers will continue to look for oillinked prices rather than accept a link to North American spot markets (see Kitimat discussion below).

Assuming that exports will go ahead from both countries the third set of issues, and the most important from a global perspective, surrounds the impact that they could have on volumes and prices in the European and Asian markets. In one sense the impact is already being felt in Europe, as LNG cargoes that had been destined for the US market have been diverted to the other side of the Atlantic in response to the US' declining import requirement. This has 
generally caused spot gas prices in Europe to decline below the level of oil-linked contract prices, leading to arbitration between suppliers and consumers, renegotiation of contracts, and a significant challenge to the whole concept of gas prices being linked to oil prices in future. Indeed gas-on-gas competition now sets the price for over half the European market, compared to only $20 \%$ in $2005,{ }^{14}$ as many consumers are now starting to insist on having access to hub-based market prices. Furthermore the impact of the US gas market in Europe is also being seen in the form of cheap coal that has been displaced from the US power sector and is being exported to Europe, where it is displacing gas in the power mix and is therefore dampening gas demand and prices.

Asian consumers have historically been more reluctant to rely on market forces to balance supply and demand and to set prices due to their concern over security of supply, and many importing companies (especially in Japan) have been willing to accept high prices both to alleviate this concern and because they could pass the cost through to end-consumers. However, utility companies in Asia are also now looking to access gas supplies at more competitive prices, in particular since the Fukushima disaster in Japan in 2011 dramatically changed the balance of fuel for power generation in favour of gas. One consequence has been an increasing search for gas supplies related to the US gas price, with one obvious potential conclusion being that the start of US LNG exports could trigger a similar change in contract terms and price formation in Asia to that which is being experienced in Europe.

One final set of questions, which build upon the working paper published by Howard Rogers for OIES in January 2012, ${ }^{15}$ concern the impact that the arrival of North American LNG exports could have on current suppliers of gas to Europe and Asia. Will spot prices fall sharply towards a US netback level? Will significant existing volumes be displaced by new North American supplies and could existing contracts be further renegotiated? How long could the impact of these new supplies last? The analysis below attempts to provide initial answers to these questions, with the caveat that many of the key underlying assumptions remain uncertain and will only be clarified over the next two to five years.

\footnotetext{
${ }^{14}$ The Economist, 14 July 2012, "Careful what you wish for: The pros and cons of a more competitive gas market in Europe”.

${ }^{15}$ Rogers, (2012).
} 


\section{Potential North American Export Projects}

To date the gas import/export trade in North America has largely consisted of gas exports from Canada to the US, some bi-lateral gas trade between Mexico and the US and finally some limited LNG imports into the US from the global LNG market. Until 2007/08 this latter trade had been expected to grow rapidly as US indigenous supply was expected to go into decline, and 12 LNG import terminals with a total capacity of 19Bcf/d of gas (196bcma of LNG) were constructed in anticipation of this developing trend. ${ }^{16}$ However, the rapid turnaround in US gas production has left many of these LNG receiving facilities redundant, and the owners are now looking to convert them into export facilities to exploit the current arbitrage opportunity between US, Asian and European gas prices. Cheniere Energy has led the way at its Sabine Pass terminal, but as detailed below a number of other operators have similar plans to transform the US LNG infrastructure from an import to an export industry.

The change in US import requirements has also had an impact on the Canadian gas industry, which has received the boost of its own shale gas discoveries but has started to lose its major export market in the US. As a result, gas producers, politicians and potential gas consumers have started to promote the possibility of LNG exports, in particular from the west coast of the country to the growing Asian market. Although these Canadian projects are not yet as numerous as those in the US, the political backing which they are receiving means that they could have an equally important impact, especially as they could also be connected either directly, or via price mechanics, to the US market.

The details of the current projects that are being proposed in Canada and the US are discussed below, with some of the key regulatory and operational issues highlighted where appropriate.

\section{Canada's gas resources}

The BP Statistical Review of World Energy provides an estimate of total proved gas reserves in Canada of 70Tcf $(2.0 \mathrm{Tcm}) .{ }^{17}$ However, this would appear to take little account of the unconventional gas potential in the country, much of which will be used as the foundation for Canada's LNG export projects. With this in mind The National Energy Board of Canada, which is the country's independent energy regulator, produced an estimate in March 2011 of the country's ultimate marketable gas resources (which are largely located in the Western

\footnotetext{
${ }^{16}$ Statistics from US Federal Energy Regulatory Commission (FERC), July 2012

${ }^{17}$ BP (2012)
} 
Canadian Sedimentary Basin). ${ }^{18}$ It identified a total of 119Tcf (3.4Tcm) of conventional gas reserves, but for the first time added significant shale gas resources located in the Horn River Basin in British Columbia totalling 78Tcf (2.2tcm).

The exploitation of Canada's unconventional gas resources is at an early stage, which means that the figure of 78Tcf is a somewhat speculative estimate, with the fact that only 3Tcf has yet been officially discovered confirming the uncertainty. However, having said this the range of estimates for the Horn River Basin is 61-96Tcf, providing significant upside as well as downside risk from the mid-case estimate, and furthermore does not include a number of prospective basins that are known to have unconventional gas potential but are as yet unassessed. As a result it would appear that the country has significant potential for gas exports, given that the total current resource estimate would cover more than 50 years of the 2011 consumption of $105 \mathrm{bcm} .{ }^{19}$ Indeed, as noted above, Canada has a particular additional incentive to encourage LNG exports because its sales of pipeline gas to the US are on a decline curve that may continue for many years, depending upon the progress of unconventional gas development made by its southern neighbour.

Table 1: Canadian Gas Resources by Province

\begin{tabular}{|l|cccccc|}
\hline & \multicolumn{3}{|c}{ Conventional } & \multicolumn{2}{c}{ Unconventional } & \multicolumn{2}{c|}{ Total } \\
& $T c f$ & $B c m$ & $T c f$ & $B c m$ & $T c f$ & $B c m$ \\
\hline Alberta & 78 & 2210 & 0 & 0 & 78 & 2210 \\
Saskatchewan & 4 & 113 & 0 & 0 & 4 & 113 \\
British Columbia & 31 & 878 & 78 & 2210 & 109 & 3088 \\
Southern Territories & 6 & 170 & 0 & 0 & 6 & 170 \\
Total & $\mathbf{1 1 9}$ & $\mathbf{3 3 7 1}$ & $\mathbf{7 8}$ & $\mathbf{2 2 1 0}$ & $\mathbf{1 9 7}$ & $\mathbf{5 5 8 1}$ \\
\hline
\end{tabular}

Source: Canadian National Energy Board

\section{Key export projects in western Canada}

The obvious alternative market, given both its proximity and growth potential, is Asia and Canadian politicians and business leaders have been making strenuous efforts to increase the commercial ties with the main Asian energy importing countries. With this in mind the province of British Colombia (BC), on Canada's west coast, is the most obvious location for the country's planned export projects, and as shown in Map 1 four current planned schemes are being developed there.

\footnotetext{
${ }^{18}$ Canadian National Energy Board Press Release, 6 April 2011, "First-time study doubles estimates of B.C. gas resources".

${ }^{19} \mathrm{BP}(2012)$
} 
Map 1: North American LNG Projects

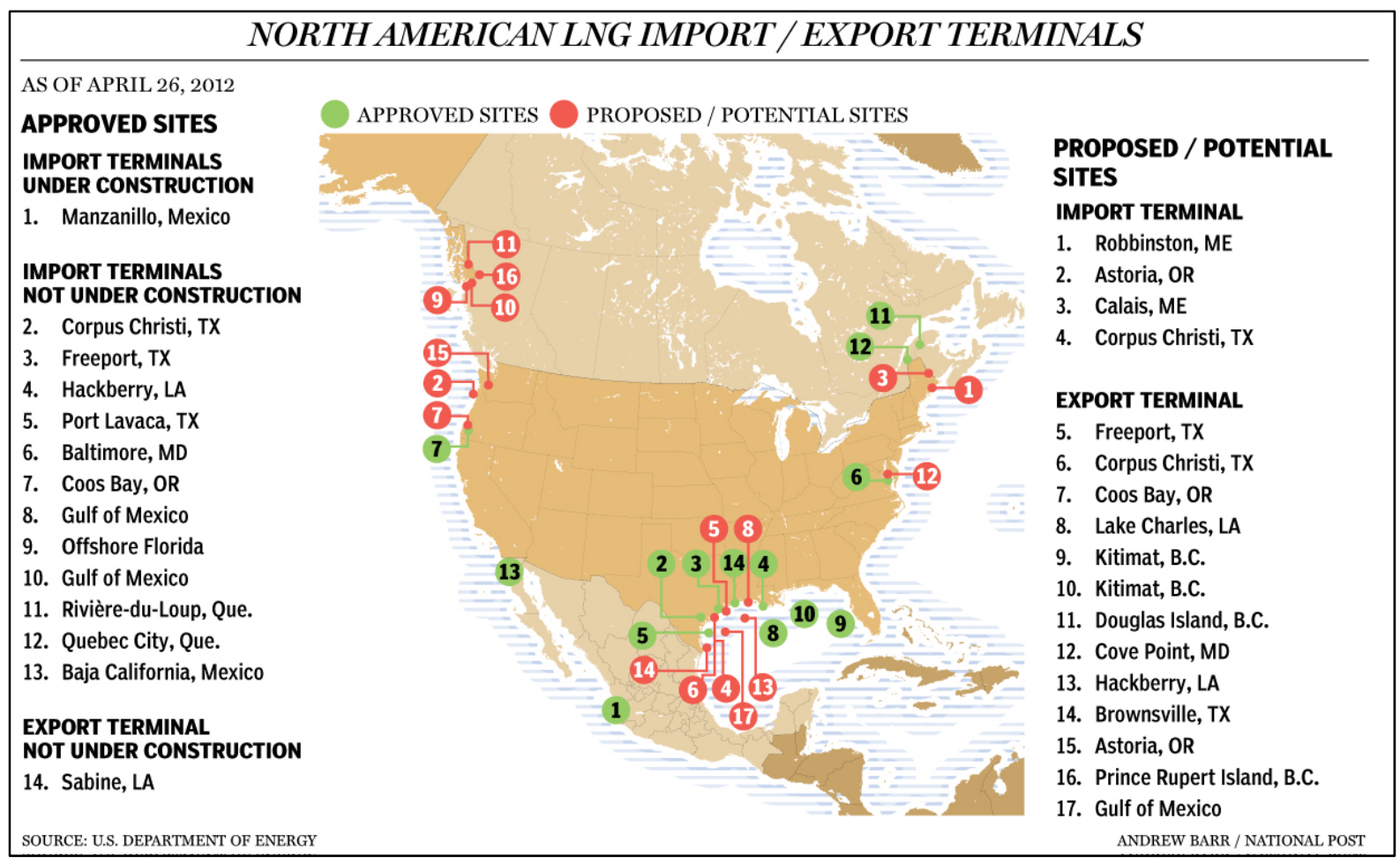

\section{Kitimat}

The Kitimat project, owned by Apache (40\%), EOG (30\%) and EnCana (30\%) is the most advanced of the three Canadian projects, having been granted a 20-year export licence by Canada's National Energy Board in October 2011 and with a final investment decision expected before the end of 2012. ${ }^{20}$ The planned capacity for phase 1 of the scheme is $5 \mathrm{~mm}$ tonnes per annum of LNG (6.7bcma), with Kogas of Korea and Gas Natural of Spain already having signed preliminary agreements to buy $40 \%$ and $30 \%$ of the output respectively. However, Apache and the other project partners are keen to sell the remainder of the gas prior to starting construction but appear to be struggling to secure further buyers for their LNG, in particular because they are looking to sell the LNG on traditional oil-linked contracts rather than at Henry Hub related prices, reflecting the higher capital costs of these greenfield projects compared to brownfield US projects relying on the currently low cost Henry-Hub priced gas as a supply source. However, the apparent reluctance of Asian buyers to sign new contracts on an oil-linked basis means that the project start-up may now have to be pushed back from 2015 to $2017 .{ }^{21}$ Ultimately the plan is to build two trains for a total capacity of

\footnotetext{
${ }^{20}$ Reuters, 29 March 2012, "EnCana Corp expects a final investment decision on Kitimat LNG project before end-2012”, Singapore

${ }^{21}$ Financial Post, 21 June 2012, “No relief for natural gas producers as Apache’s Kitimat plant is delayed”, Toronto
} 
$10 \mathrm{Mt}$, but this will rely on a price formula being found that can meet the desire of the sellers for an oil-linked contract and the new ambition of many Asian buyers to link purchases from North America to spot markets. A compromise might entail linkage to Henry Hub (or a comparable Canadian hub price) with a higher margin to remunerate project capital cost, when compared with US brownfield LNG export projects.

The gas to supply the plant is primarily being sourced from the gas assets owned by Apache, EOG and Encana in British Columbia (BC) and Alberta, in particular from resources in the Horn River Basin in north-east BC. Apache and EnCana have joint control of approximately 430,000 acres in the area with gas resources totalling 10Tcf $(280 \mathrm{bcm})$, while EOG has a further 9Tcf $(255 \mathrm{bcm})$ of gas resources located in the 157,500 acres of territory that it controls. $^{22}$ In addition Apache announced in June 2012 that it had identified a further 48Tcf $(1.35 \mathrm{tcm})$ of net estimated sales gas in the Liard Basin in northern BC, increasing the total potential gas available to the Kitimat project to $66 \mathrm{Tcf}(1.9 \mathrm{tcm})$, equivalent to 280 years of throughput under Phase 1 capacity. Importantly the companies involved in the project have additional back-up supplies in the US, and the project is connected to the North American gas grid. As a result, security of supply is clearly not an issue, as the project partners would appear to have a wide range of alternative sources of production which they can utilise according to the economics and cost of each source.

In terms of marketing the LNG, the project partners estimate that the fully laden transport time to Asia is 11 days, meaning not only that transport costs are relatively low but also that the plant can be fairly flexible in terms of reacting to spot markets. Although the details of the contracts with Kogas and Gas Natural have not been revealed, and are at present only in MoU form, it would appear that the project partners are keen to secure long-term (20 year) contracts for a majority of their output, but may also market some of the gas on a short-term basis in order to exploit arbitrage opportunities.

\section{LNG Canada}

The largest of Canada's currently planned LNG export projects is also near Kitimat, and is owned by the LNG Canada consortium that comprises a mixture of one producer (Shell Canada) and three potential consumers in Asia (Kogas from Korea, Mitsubishi from Japan and PetroChina from China). As a result, although the project is currently only at the

\footnotetext{
${ }^{22}$ http://www.kitimatlngfacility.com/Supply/natural_gas_supply.aspx, accessed on 6 August 2012
} 
feasibility study stage it would appear to have significant momentum towards becoming a major Canadian export project. Indeed in July 2012 the project partners applied to the National Energy Board for a 25-year export licence which would underpin the development of the liquefaction plant and its associated transport and storage facilities. ${ }^{23}$

The project plan is to build two 6mtpa trains for a total ultimate initial capacity of $12 \mathrm{mtpa}$ (c.17bcma), with the potential for future expansion if sufficient demand is found. The plant will be connected via a new 700 kilometre pipeline to fields in the north of British Columbia, with the gas most likely to be sourced from Shell Canada’s Groundbirch assets. PetroChina, a fellow partner in the LNG Canada consortium, purchased a 20\% interest in this gas resource in February 2012, ${ }^{24}$ where the production potential is estimated to be as high as $1 \mathrm{Bcf} / \mathrm{d}$ (10.3bcma). ${ }^{25}$ Shell already produces more than 0.5Bcf/d (5bcma) in Canada and has extensive onshore and offshore assets that could ultimately provide further gas to the LNG Canada facilities. However, first LNG exports from the scheme are not expected until towards the end of the decade, with a final investment decision likely to be taken in 2014/15 when all regulatory approvals have been received and environmental studies have been completed.

\section{Lelu Island (Petronas/Progress Energy)}

A third major LNG export scheme in the Kitimat area has been proposed by Petronas, the Malaysian NOC, and Progress Energy, a Canadian gas producer that is currently the subject of a C $\$ 5.2$ billion takeover bid by Petronas. ${ }^{26}$ Assuming that the takeover deal is approved by the Canadian government following a review that is due to be concluded in October 2012, the two companies plan to construct a two train 7.4mtpa liquefaction plant on Lelu Island near Prince Rupert. Gas would be sourced from Progress Energy’s Canadian upstream assets, and the most aggressive export timetable would see first sales of gas to Asia in 2018. However, this would be subject to all the regulatory approvals being received and a final investment decision being taken by the second half of 2014. Nevertheless, even if this timetable is ultimately too optimistic, Petronas and Progress will be in a strong position to market Canadian gas into the Asian market as the consortium will have access to all elements of the

\footnotetext{
${ }^{23}$ LNG Canada press release, 30 July 2012, "LNG Canada applies to the National Energy Board for a 25 year export licence".

${ }^{24}$ Oil \& Gas Journal, 6 Feb 2012, "PetroChina to buy 20\% of Shell’s Canadian shale gas assets”.

${ }^{25}$ Financial Post, 2 Feb 2012, "PetroChina buys Canadian shale gas stake from Shell”.

${ }^{26}$ Platts, 28 June 2012, “Deal just announced, Petronas and Progress say eye speeded LNG export decision”.
} 
supply and marketing chain thanks to the combination of Petronas' long experience of selling LNG into the Asia Pacific region and Progress Energy’s upstream asset base.

\section{Douglas Island}

A fourth, much smaller LNG export scheme is being planned at Douglas Island, again close to Kitimat, by the Douglas Channel Energy Partnership, a privately-owned consortium in British Columbia. Working in tandem with the BC LNG Export Co-operative, ${ }^{27}$ the Douglas Island project aims to provide an export outlet for a group of natural gas producers in Western Canada via an independent LNG export facility. The initial plan is for plant capacity of just under 1mtpa of LNG (1.2bcma), becoming operational in early 2014 if all the appropriate regulatory approvals are received on time. An initial export licence application was filed with the National Energy Board in March 2011, ${ }^{28}$ but official approval has yet to be documented, meaning that a 2015 or 2016 start date is now probably more realistic.

Finally BG Group announced in September 2012 that it is planning a joint venture with Spectra Energy to build an 850 kilometre pipeline from the shale deposits in northern British Columbia to the Kitimat region. ${ }^{29}$ BG Group has also opened negotiations with the regional authorities at Prince Rupert for the construction of a liquefaction plant that could take some or all of the 4.2Bcf/d capacity of the planned new pipeline capacity and convert it into LNG exports for the Asian market. Plans for both the pipeline and LNG liquefaction plant are at a very early stage at present (and are not included in Table 2 below due to a lack of available data), but the negotiations for a fifth potential LNG facility in Western Canada emphasize the growing export potential from the region.

\section{Conclusions on Canadian LNG projects}

A number of critical factors are combining to suggest that Canada will become a key exporter of gas from North America over the next 5-10 years. Firstly, it appears to have an increasingly significant gas resource base, founded on its conventional gas reserves but now also growing thanks to its rapidly emerging unconventional gas plays. These resources are generally located in the west of the country, largely in British Columbia, making them well placed for any Asia-focused export projects on the west coast. It is therefore no surprise that

\footnotetext{
${ }^{27}$ A corporate entity formed to purchase LNG from the proposed liquefaction terminal

${ }^{28}$ Douglas Channel Energy Partnership Press Release, 8 March 2011, "BC LNG Export Co-operative files application with Canada’s National Energy Board for a natural gas export licence”, Vancouver

${ }^{29}$ Reuters, 10 Sept 2012, "BG, Spectra planning BC pipeline to serve LNG plant"
} 
it is the key participants in these unconventional plays (Apache, EOG, EnCana and Shell) who are sponsoring the initial LNG projects, which are all located close to the deep waters near Kitimat. Furthermore, likely Asian buyers of Canadian gas such as Kogas, PetroChina and Mitsubishi are also now becoming involved in both the upstream and liquefaction projects that will supply the export volumes, with other Asian players such as Petronas also now bidding to buy into gas assets to bolster their position as suppliers to eastern gas markets. $^{30}$

Secondly, Canada's traditional gas export business to the US is in decline, and the country is keen to replace its lost export revenues. The shale gas revolution in the US has led to a 20\% fall in Canadian pipeline exports to its southern neighbour since 2007, and this decline looks set to continue if the exploitation of unconventional gas resources in the US continues to meet rising expectations. Asia is the obvious alternative market to which Canada can sell its excess gas, and the political will to promote this avenue of commercial activity has been clearly demonstrated through the recent visits by the Canadian Prime Minister to China and other key gas importing countries (see later discussion on politics).

Thirdly, Canadian gas demand would appear to be amply covered not only by its indigenous resources but also by its connection to the US gas market. Although at present this connection acts as a route for exports, it could equally provide a source of imports to meet rising demand if necessary, or to act as an alternative export option for US gas if the US authorities attempt to limit US LNG export plans. The connection with the US also means that the Canadian gas price is closely linked to spot prices such as Henry Hub (as shown in Figure 3), meaning that the price arbitrage for Canadian producers who are comparing North American sales opportunities with exports to Asia is very large. Having said that, although the comparison between Asian and North American gas prices is relevant, and at present certainly favours the LNG export option, it must also be considered that Canada's export projects are based on greenfield sites that will demand a minimum price level to justify their capital costs. As a result the gas producers clearly have a third option, namely not to develop their gas fields for the domestic market or for LNG exports, if the price for the latter is not adequate. Therefore the price considerations for Canada's export projects will be driven by the requirement to remunerate higher project unit capital costs compared with the brownfield US projects discussed below.

\footnotetext{
${ }^{30}$ Financial Times, 28 June 2012, "Petronas of Malaysia to buy Canada’s Progress Energy Resources for \$5.3bn".
} 
Figure 3: Gas prices in Canada and the US

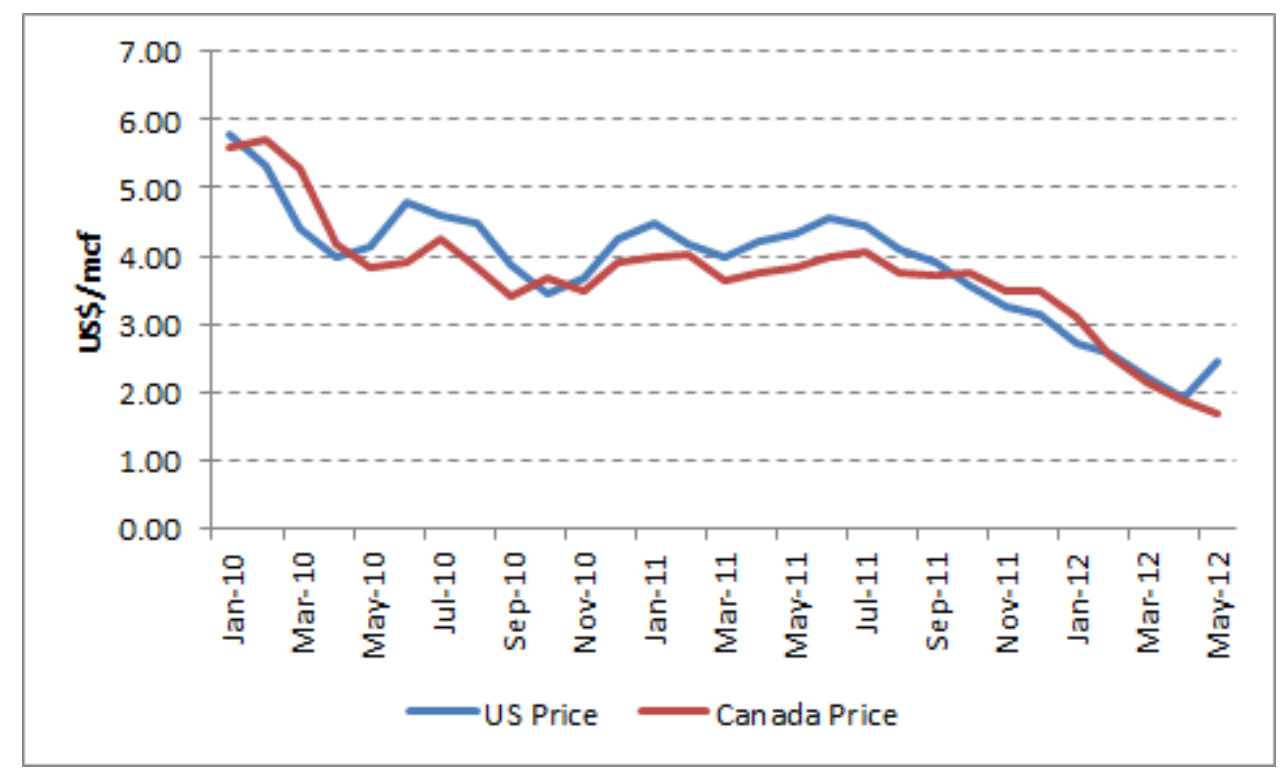

Source: National Energy Board of Canada

With this proviso on price and assuming that a greenfield LNG liquefaction scheme will take approximately 4-5 years to develop, it would nevertheless seem probable that Canada could be exporting 20-30mtpa of LNG by the end of this decade, or shortly thereafter in the event of some project delays. The main caveat would be that buyers need to be secured to underpin the financial commitments required to construct the projects, with the example of the potential delays at Kitimat demonstrating that even in an Asian market with fast-growing gas demand this is far from a certainty. Nevertheless, the prospects for Canadian LNG exports continue to look bright, in particular because two of the three key projects (LNG Canada and Lelu Island) involve the active participation of future Asian consumers of Canadian LNG. Overall, then, it would seem reasonable to expect that Canada could be exporting at least the 19mtpa (26bcma) of LNG planned for these two projects by 2020, with potential for an extra 5-10mtpa of exports from the Kitimat project if the current pricing issues can be resolved.

\section{Potential US gas export projects}

The commercial logic for US LNG exports was made very clear in the first half of 2012 when US gas prices fell to a $\$ 2-3 /$ mmbtu range, driven by a significant excess of supply over demand. The differential between domestic prices and those on offer in international markets has been so great that even after the inclusion of gas purchase, liquefaction and transport costs a significant margin would have been available to any gas exporting company. Furthermore, although the domestic gas price in the US would appear to be unsustainably low 
at present, especially given the economics of dry unconventional gas production, ${ }^{31}$ the increasing development of wet unconventional gas reserves has meant that the economics of gas production have been improved by the sale of associated oil and natural gas liquids (see later for a more detailed discussion on export margins and the breakeven cost of US gas reserves). With the US undeveloped shale gas resource recently estimated by the EIA (Energy Intelligence Agency) at up to 750Tcf (c.20Tcm), in addition to an existing proved conventional and unconventional reserve base of 300Tcf $(\mathrm{c} .8 .5 \mathrm{Tcm})$, there would also appear to be sufficient gas resources in place to sustain this fully supplied position for some time (with the caveat that estimates of unconventional gas resources in the US are constantly being revised as production data is gathered and analysed).

As a result of this situation the gas market balance in the US has changed dramatically over the past 5 years, with the country now moving towards gas self-sufficiency as opposed to the gas deficit that was expected. As has been noted above, gas imports from Canada have already gone into decline, and a further consequence of this changing market balance has been that the numerous LNG receiving terminals that had been built to cater for an anticipated rise in LNG imports are now redundant. Many of the owners of this receiving capacity, which includes storage, transport and port facilities that can be used for gas flow in either direction, are now looking to utilise their plants for LNG exports by constructing liquefaction facilities, while others are even looking to build greenfield liquefaction facilities

\section{Cheniere Energy is leading the way at Sabine Pass}

Cheniere Energy's Sabine Pass terminal is a prime example of a project initially conceived as an import scheme that is now directing its facilities towards gas exports. In 2008 stage 1 of the receiving terminal came into operation, with the first part of stage 2 starting in 2009 but then halted as it became clear that the US would no longer have a significant import requirement. As a result the $16.8 \mathrm{Bcf}$ of storage and $2.6 \mathrm{Bcf} / \mathrm{d}$ of send-out capacity is largely idle, while the port facilities, which can handle up to 400 LNG vessels per annum via the 2 berths in its docks, are available for loading of gas for export as well as for unloading of imports.

Happily for Cheniere the location of the Sabine Pass terminal on the coast of the Gulf of Mexico close to the border of Texas and Louisiana means that it is well placed to tap into the

\footnotetext{
${ }^{31}$ The IEA World Energy Outlook 2011 suggests that North American shale gas resources would require prices in the range \$3-7/mmbtu to be economic (WEO 2011, p.161)
} 
gas supplies from the southern states of the US. It has invested in the purchase of the Creole Trail Pipeline to provide a 94-mile link to the main US gas pipeline system, meaning that by 2014 it will be able to source gas at Henry Hub market prices for liquefaction and export.

The liquefaction project itself is currently planned to consist of 4 trains each with a nominal capacity of $4.5 \mathrm{mtpa}$ for a total of 18mtpa of LNG (21.6bcma, 2.1Bcf/d), coming on-stream in stages from 2015 to 2018. ${ }^{32}$ Construction of Trains 1 and 2 has commenced in 2012 and Trains 3 and 4 are expected to see work begin in 2013, meaning that the US is on schedule to have its first LNG exports within 3 years. Export contracts have been signed with BG, Gas Natural, Kogas ${ }^{33}$ and Gail (of India) to export approximately 16mtpa, with the contracts essentially offering each buyer gas at Henry Hub prices plus a 15\% premium plus a fixed fee to cover the operating costs of the liquefaction plant, giving them the opportunity to exploit arbitrage opportunities between the US and other global gas markets. Importantly, though, the contracts do not involve a binding commitment to take gas, meaning that if Henry Hub prices rise the exporters can refuse the gas, although they are still obliged to pay the fixed fee (effectively as an option cost). The potential implications of this contract structure on global gas prices will be discussed in more detail in Section 4. The remaining 2 mtpa of liquefaction capacity at Sabine Pass will provide LNG that will be traded by Cheniere itself on the spot market.

Plans for a possible $5^{\text {th }}$ LNG train at Sabine Pass have also been discussed with Total, one of the companies with a long-term lease agreement for the regasification capacity at the site. Under the terms of the proposal, announced by Cheniere Energy in September 2012, Total would provide storage and berthing capacity at its facilities in return for low cost access to a future expansion of the Sabine Pass liquefaction plant. However, this concept is currently only at the evaluation phase and would require full permitting by the US authorities before any concrete plan could be implemented. ${ }^{34}$

\footnotetext{
${ }^{32}$ Cheniere Energy presentation, Citi Global Energy Conference, June 5, 2012, slide 9

${ }^{33}$ Note that widening of the Panama Canal, estimated to be completed in 2014, will shorten the distance (and hence the shipping cost) between the Gulf of Mexico LNG export facilities and Asian LNG markets.

${ }^{34}$ Source - Cheniere press release and newspaper article from David L
} 
However, the more complicated process that Cheniere has had to negotiate, and which still faces the other companies hoping to follow its example, is that of application for approval by the US regulatory authorities. This process involves two main regulatory bodies, the Federal Energy Regulatory Commission (FERC) and the Department of Energy, Office of Fossil Energy (DOE/FE), with the former dealing with permits to construct and operate the LNG facilities while the latter provides authorisation for exports. A number of other less high profile, but nevertheless important, approvals are also required concerning the Coast Guard, the Fisheries Service, Clean Water and Clean Air permits and various local and state permits, all of which add to the time taken to gain overall permission to proceed, but the FERC and $\mathrm{DOE} / \mathrm{FE}$ regulations are the real key to a project being allowed to commence. ${ }^{35}$

The FERC essentially co-ordinates all the federal authorisations needed to site, construct and operate the industrial plant required, reviewing all the detailed engineering plans and ensuring that all the conditions of the National Environmental Policy Act are met. In the case of projects such as Sabine Pass it specifically analyses all the potential LNG hazards, establishes emergency response plans and then inspects and oversees both the construction and the on-going operation of the LNG facilities, with a requirement for a full reporting schedule of plant performance. In summary, a gas liquefaction facility cannot be constructed and operated without full FERC approval.

The DOE/FE regulations concern the right to export a product, and in particular focus on whether such exports are deemed to be in the public interest. Furthermore the approval needs to be given twice, once for countries with which the US has a Free Trade Agreement (FTA countries) and then again for countries with whom it does not (non-FTA countries). This is particularly important in the case of LNG exports because only one of the 19 FTA countries is a significant gas importer (South Korea) ${ }^{36}$ and therefore no LNG export project could realistically hope to be a commercial success without non-FTA approval. FTA approval is essentially automatic, as it is assumed that trade with FTA countries is in the public interest, but non-FTA approval is more complex and may involve a public hearing if interested lobby groups want to argue that exports could harm their interests. Further, authorisation may also

\footnotetext{
${ }^{35}$ Nevins (2012).

${ }^{36}$ Data from the Office of the United States Trade Representative at http://www.ustr.gov/trade-agreements/freetrade-agreements, accessed on 8 August 2012
} 
be granted with conditions and is not necessarily binding for the life of any project, meaning that it could be revoked if circumstances are deemed to have changed.

Cheniere Energy has received all the required authorisations to proceed with the Sabine Pass plant, including (in May 2011) the vital DOE/FE non-FTA export approval ${ }^{37}$ and the FERC construction approval (in April 2012). ${ }^{38}$ As a result turn-key contracts for the construction of the plant have been signed, financing has been secured and the building of the liquefaction plant is currently underway, with first LNG exports scheduled for 2015.

\section{Cheniere's second export project at Corpus Christi is at a much earlier stage}

Cheniere is planning a second liquefaction and export facility in Corpus Christi Bay on the coast of Texas on a site that has previously been permitted for imports. The current plan is to build a three train facility with a total ultimate capacity of 13.5mtpa of LNG (18bcma), and at present the FERC regulatory process to gain approval for construction has just begun. The project schedule currently envisages building work to commence in October 2013, with first LNG exports by the end of 2017, but this is a tentative estimate at present given that no DOE/FE export permits have yet been granted. In addition, given the greenfield nature of the project it would seem more realistic to anticipate first possible LNG exports from 2020 or beyond.

Interestingly, though, the potential plant is well situated to access gas from the Eagle Ford shale play 70 miles to the northwest, and so the project will clearly rely on the potential of the US unconventional gas resources being realised. A Cheniere-sponsored study by the United States Geological Survey has estimated gas resources in this play alone at 180Tcf (c.5Tcm), but clearly the DOE/FE will need to decide whether this gas provides a sufficient resource to underpin an export project rather than being held back for the domestic market.

Seven more LNG export projects have already been proposed to the FERC

In addition to Sabine Pass a further seven LNG export projects have already been proposed to the FERC, with the Freeport facility, located in Texas, being one that has signed tolling agreements with non-FTA partners in anticipation of ultimate government approval. In July 2012 20-year liquefaction tolling agreements were signed with Osaka Gas and Chubu

\footnotetext{
${ }^{37}$ LNG World News, 21 May 2011, “Cheniere wins additional DOE approval for LNG export”, sourced from www.lngworldnews.com on 8 August 2012

${ }^{38}$ Cheniere Energy News Release, 16 April 2012, “FERC approves the Sabine Pass Liquefaction Project”, Houston
} 
Electric, both Japanese utility companies, covering the full 4.4mtpa capacity of the first train that is planned at the plant. ${ }^{39}$ A further two trains are planned to take the full capacity of the facility to 13.2mtpa, and Freeport expects that it will have signed agreements to cover this extra capacity by the end of 2012. Again approval from the DOE/FE to allow exports to nonFTA countries is still awaited, as is approval from the FERC to begin construction work. Assuming that these are received by mid-2013 (as anticipated by Freeport LNG) then construction work would begin in the third quarter of 2013 and would be completed 4 years later, implying a start-up date for the first train in late 2017 and for the subsequent trains in 2018.

The Cameron receiving terminal at Hackberry operated by Cameron LNG, an affiliate of Sempra, currently plans to convert to an LNG export facility on a similar timescale to Freeport. The 1.5Bcf/d (15bcma) regasification facility began operations in 2008 and is connected to 5 inter-state pipelines via a 35-mile pipeline link and, as with all regasification terminals, has existing docking and storage facilities that could be converted for exports. In January 2012 Cameron LNG received a licence from the DOE to export up to 12mtpa to FTA countries, and in April 2012 submitted its initial request to the FERC to mark the start of the construction approval process. ${ }^{40}$ It is currently anticipated that this approval process will be completed by the end of 2013, after which $\$ 6$ billion of incremental investment will be spent on three trains with 4mtpa of capacity each, with first LNG being produced in December 2016 and all three trains being completed in December 2017.

Once again, however, the commercial viability of the plant will depend upon receipt of approval to export to non-FTA countries, and in this regard it is interesting to note that Sempra has signed binding agreements with Mitsubishi and Mitsui from Japan and GDF Suez from France (both non-FTA countries) to fund all the development expenses for the new plant. ${ }^{41}$ The agreements also commit the participants to negotiate 20-year tolling agreements which will cover the full capacity of the plant, although these will surely depend upon final DOE approval to give the facility non-FTA status, for which an application has been made and a decision is pending. As a result, although the Hackberry scheme would appear to have

\footnotetext{
${ }^{39}$ Freeport LNG Press Release, 31 July 2012, “Freeport LNG signs 20-year tolling agreements with Osaka Gas and Chubu Electric”.

${ }^{40} \mathrm{http}$ ://cameron.sempralng.com/liquefaction.html, accessed on 9 August 2012

${ }^{41}$ Sempra Energy Press Release, 3 May 2012, "Sempra Energy Unit signs commercial agreement with GDF Suez for remaining capacity at liquefaction plant”.
} 
significant commercial backing, its future continues to depend upon political sentiment in the US towards gas exports.

The Lake Charles regasification facility, also located in Louisiana, is the largest of the potential gas export projects from the US for which applications to the FERC are progressing with the current import terminal being owned and operated by TrunkLine LNG (a subsidiary of Southern Union) but being fully contracted to BG until $2030 .{ }^{42}$ BG has used the terminal since 2001 to bring gas into the US and distribute it via the 15 major intra- and inter-state pipelines to which the facility has access, but in May 2011 BG and Southern Union applied to the DOE/FE for an export licence and were granted initial approval to export up to 15mtpa of LNG to FTA countries. ${ }^{43}$ The possibility of an upgrade in this licence to non-FTA status is being considered and would likely be a necessary condition for the construction of a liquefaction plant that would provide BG with the flexibility to export the gas produced by its unconventional gas assets located in east Texas and northern Louisiana (the Marcellus and Haynesville shale plays). At present, though, BG CEO Frank Chapman has underlined that "we have taken the step to apply for an export licence, simply to provide a further future business option”. ${ }^{44}$ As documented by the FERC, the Lake Charles export scheme could have the capacity to produce $18 \mathrm{mtpa}$ of LNG (24bcma or $2.4 \mathrm{Bcf} / \mathrm{d})$.

An additional liquefaction project that has been proposed to the FERC is in Maryland, again at an existing terminal at Cove Point. The facility is being planned and will be operated by Dominion and is expected to have a capacity of 6mtpa (approximately $0.75 \mathrm{Bcf} / \mathrm{d}$ or $8 \mathrm{bcma}$ ), and the FERC regulatory process was initiated in April 2012, with approval anticipated by the end of 2013. Construction would then commence, and the facilities would be available, as with a number of the other plants, by 2017. DOE/FE approval for exports to FTA countries was received in October 2011, and at the same time an application was also made for exports to the more important group of non-FTA countries. Again, as with the other proposed facilities above, approval is pending. ${ }^{45}$

One of the major features of Cove Point, which may perhaps give it an advantage over its rival export projects, is its proximity to the Marcellus shale play and the involvement of Statoil as a potential partner. Statoil has a long-term gas import contract with Dominion at

\footnotetext{
${ }^{42}$ http://www.bg-group.com/OurBusiness/WhereWeOperate/Pages/UnitedStatesofAmerica.aspx accessed on 9 August 2012

${ }^{43}$ ICIS Heren, 13 May 2011, "BG Group lays foundation for future US LNG exports"

${ }^{44}$ Ibid

${ }^{45}$ https://www.dom.com/business/gas-transmission/cove-point/index.jsp, accessed 9 August 2012
} 
Cove Point, but as part of the plan to turn the facility into an export terminal this contract has been shortened from 18 to 10 years and talks have begun to explore the opportunity to send gas from Statoil's assets in the Marcellus shale play for export via the new liquefaction project. ${ }^{46}$ Furthermore Japanese companies Sumitomo and Tokyo Gas have agreed to buy a combined 2.3mtpa of LNG from the plant under a twenty year contract, with Sumitomo also keen to supply the facility with gas from its assets in the north-east of the US. ${ }^{47}$ As a result, it would appear that the Cove Point project is making progress towards its goal of exports by 2017, although the crucial DOE/FE approval still needs to be granted.

Two further liquefaction projects are planned in the state of Oregon, again based on existing or planned regasification terminals. The first is at Coos Bay (Jordan Cove) where a 6mtpa liquefaction facility is planned and where a full FERC application for construction is expected to be made by October 2012. ${ }^{48}$ An application has also been made to the DOE/FE for an export licence to cover non-FTA countries, ${ }^{49}$ and a speculative date for first LNG exports has been put at the third quarter of 2017, assuming that all regulatory approvals are received over the next 12-18 months. ${ }^{50}$ The second planned facility in Oregon, at Astoria and run by Oregon LNG, has a similar timeline but appears to be somewhat more speculative in nature. Originally conceived as an import terminal in 2007, the application to the FERC was altered in April 2012 to include export facilities and Oregon LNG now aims to provide a bidirectional facility that can offer peak-shaving gas for import but can also provide exports on a tolling basis. The plant is planned to have an export capacity of $1.3 \mathrm{Bcf} / \mathrm{d}$ (10mtpa or 13.5bcma), and an application was made to the DOE/FE in July 2012 for approval of exports to non-FTA countries at this level, but as the Astoria facility appears to be somewhat behind its competitors and has yet to secure any tolling agreements it would seem that the planned date for first exports of 2017 may be somewhat optimistic. Having said that, the location of both of these Oregon projects on the west coast of the US offers them the benefit of a much shorter and cheaper transport route to the Asian gas market, meaning that they are likely to be able to offer more competitive prices than their competitors on the east coast.

\footnotetext{
${ }^{46}$ Reuters, 1 Feb 2011, “Dominion eyes Cover Point exports by 2015".

${ }^{47}$ Bloomberg, 27 April 2012, "Sumitomo, Tokyo Gas secure US LNG from Dominion for Japan".

${ }^{48}$ http://www.jordancoveenergy.com/news.htm, accessed on 9 August 2012

49 Application was made in March 2012

${ }^{50}$ Zeus Intelligence, 11 Nov 2011, "Jordan Cove updates export timetable", from http://member.zeusintel.com/ZLNGR/news details.aspx?newsid=25100, accessed on 9 August 2012
} 


\section{Other possible export projects}

Five other potential export projects that are either at the very start of the regulatory process or have yet to make applications. The Brownsville facility proposed by Gulf Coast LNG has made an application to the DOE/FE for a licence to export up to 29bcma (approximately 21.5mtpa of LNG), ${ }^{51}$ while at Lavaca Bay in Texas Excelerate Liquefaction plans to build the first floating LNG export plant in the US. ${ }^{52}$ Initial capacity at the plant would be 3-4mtpa, but could be expanded to 8mtpa if required, with an estimated start-date of 2017 if approvals are received, with gas being taken from the South Texas pipeline on a tolling basis. The Pascaguola receiving terminal run by Gulf LNG only opened in October 2011, but despite being fully contracted for 20-years of potential gas imports it has only received two shipments since its inauguration and is now considering the option to become an export facility. ${ }^{53}$ DOE/FE approval has been granted to allow the export of $11.5 \mathrm{mtpa}$ of LNG, but no concrete construction plans or approvals have been received yet and so the future of a possible liquefaction plant remains very much at the conceptual stage. El Paso has also applied to the DOE/FE for a licence to export 0.5Bcf/d (4mtpa of LNG) from its import facility at Elba Island in Georgia. ${ }^{54}$ Again, the export project is very much at an early stage, with the FERC approval process yet to be started. Finally, in August 2012 ExxonMobil and Qatar Petroleum announced that they would be seeking approval to add a 15.6mtpa (21bcma, 2Bcf/d) liquefaction facility at their Golden Pass terminal in Texas. Investment of \$10 billion in the project is planned, and the backing of two powerful and influential partners would appear to give the project significant credibility, but as yet no specific timetable for first gas exports has been stated. Nevertheless, the project marks an interesting change of strategy by ExxonMobil, which in 2010 declared that it saw no future for US gas exports but now appears to be taking an opposite view of US gas market prospects. ${ }^{55}$

\footnotetext{
${ }^{51}$ US Federal Register, 4 June 2012, “Gulf Coast LNG Export, LLC; Application for Long-Term Authorization to Export Domestically Produced Liquefied Natural Gas for a 25-Year Period".

52 Reuters, 15 May 2012, "Excelerate to build first floating US LNG export plant”.

53 Alabama News, 28 June 2012, "Pascaguola's LNG import facility could see exports as well”.

${ }^{54}$ Reuters, 18 May 2012, “El Paso applies for US LNG export licence for Elba Island”.

${ }^{55}$ Interfax Gas Daily, 22 Aug 2012, “Golden Pass export project highlights US market shift”.
} 
Table 2: Proposed and Potential LNG Export Projects in North America

\begin{tabular}{|c|c|c|c|c|c|c|c|}
\hline & Location & Capacity & & & $\begin{array}{c}\text { Target Start- } \\
\text { Up* }\end{array}$ & $\begin{array}{l}\text { Current Export } \\
\text { Licence Status }\end{array}$ & Owners \\
\hline United States & & $B c f / d$ & bcma & Mtpa & & & \\
\hline Approved & & & & & & & \\
\hline Sabine Pass & Louisiana & 2.1 & 21.6 & 16.0 & 2015 & Unrestricted & Cheniere Energy, Sabine Pass LNG \\
\hline \multicolumn{8}{|l|}{ Proposed to FERC } \\
\hline Freeport & Texas & 1.7 & 17.8 & 13.2 & $2017 / 18$ & FTA only & ConocoPhillips and multiple partners \\
\hline Corpus Christi & Texas & 1.8 & 18.2 & 13.5 & 2018 & Filed with FERC & Cheniere Energy, Corpus Christi LNG \\
\hline Coos Bay & Oregon & 0.8 & 8.1 & 6.0 & 2018 & FTA only & Jordan Cove Energy Project \\
\hline Lake Charles & Louisiana & 2.4 & 24.3 & 18.0 & 2018 & FTA only & Southern Union, Trunkline LNG (BGF) \\
\hline Cameron & Louisiana & 1.6 & 16.2 & 12.0 & $2017 / 18$ & FTA only & Sempra, Cameron LNG \\
\hline Cove Point & Maryland & 0.8 & 8.1 & 6.0 & 2017 & FTA only & Dominion \\
\hline Astoria & Oregon & 1.3 & 13.5 & 10.0 & 2017 & Filed with FERC & Oregon LNG \\
\hline Approved \& Proposed & & 12.4 & 127.9 & 94.7 & & & \\
\hline \multicolumn{8}{|l|}{ Other Potential Projects } \\
\hline Brownsville & Texas & 2.8 & 29.0 & 21.4 & na & & Gulf Coast LNG Export \\
\hline Pascaguola & Mississippi & 1.5 & 15.5 & 11.5 & na & & Gulf LNG Liquefaction \\
\hline Lavaca Bay & Texas & 1.0 & 10.8 & 8.0 & 2017 & & Excelerate Liquefaction \\
\hline Elba Island & Georgia & 0.5 & 5.4 & 4.0 & na & & Southern LNG Company \\
\hline Golden Pass & Texas & 2.0 & 21.1 & 15.6 & na & & Exxon, Qatar Petroleum \\
\hline Potential & & 7.9 & 81.8 & 60.5 & & & \\
\hline Total USA & & 20.3 & 209.7 & 155.2 & & & \\
\hline \multicolumn{8}{|l|}{ Canada } \\
\hline Proposed & & & & & & & \\
\hline Kitimat & British Colombia & 1.3 & 13.5 & 10.0 & 2017 & Secured NEB & Apache, EOG, Encana \\
\hline LNG Canada & British Colombia & 1.6 & 16.2 & 12.0 & 2019 & Applied to NEB & Shell Canada, KOGAS, Mitsubishi, PetroChina \\
\hline Lelu Island & British Colombia & 1.0 & 10.0 & 7.4 & 2018 & Proposed & Petronas, Progress Energy \\
\hline Douglas Island & British Colombia & 0.1 & 1.2 & 0.9 & 2014 & Applied to NEB & BC LNG \\
\hline Sub-Total & & 4.0 & 40.9 & 30.3 & & & \\
\hline Total Canada & & 4.0 & 40.9 & 30.3 & & & \\
\hline Total North America & & 24.2 & 250.7 & 185.5 & & & \\
\hline
\end{tabular}

Source: FERC as of July 2012, Company data

\section{Conclusions on North American LNG Export Facilities}

The prospects for LNG exports from North America would appear to be strong, given the number of projects that are currently being planned, and while most of the attention has been focused on the US it may well be the case that Canada provides an equally important new source of supply to global markets despite the smaller overall size of the projects being planned. With a growing resource base of unconventional gas, declining sales of exported gas to the US due to the latter's own growing gas resources and a political appetite for enhanced commercial relations with Asia, and China in particular, Canada's four planned LNG export projects seem set to move ahead on a schedule that could see 20-30mtpa of LNG being exported by 2020. This would effectively make up for the decline in pipeline export sales to 
the US over the past five years, and given that this decline is expected to continue it would not be surprising if additional Canadian export projects were to be proposed and approved over the next few years. As a result the outlook for growing gas exports appears very robust.

The situation in the US appears more uncertain, because although a number of projects have been proposed and a number have initial export approval to FTA countries, questions about the potential impact of gas exports on the domestic market are still being asked in political circles (see next section). At the present time only one LNG export project, at Sabine Pass, has been fully approved for construction with an unrestricted export licence, while seven other projects have been proposed to the FERC, but all lack the vital export licence to nonFTA countries that is critical for their commercial viability. The political debate about granting these export licences is likely to continue until after the US Presidential Elections in November, and it is interesting to note that all of the projects that have stated schedules do not anticipate approval before mid-2013 at the earliest, with 2017 or 2018 then the anticipated start-up date.

If all seven projects, plus Sabine Pass, were to go ahead Table 2 shows that the US could be exporting almost 95mtpa of LNG by 2020, or 12.4Bcf/d (128bcma), equivalent to $19 \%$ of domestic gas demand in 2011. ${ }^{56}$ If the five additional possible export facilities are added this figure for exports could increase to over 150mtpa of LNG (190bcma) or more than a quarter of domestic demand, but there must be considerable doubt as to whether this is really achievable. Concerns over rising gas prices have already sparked a political reaction which is questioning the need to approve so many export facilities, and as discussed in the next section the US Administration would appear to have a significant choice to make between adhering to free market principles or responding to the increasingly vocal industrial lobby groups who are opposed to any exports that could potentially increase their own energy costs. However, although the political decisions will be important, commercial factors are also likely to play a role in controlling the extent of US LNG exports, as rising domestic gas prices could reduce the incentive to export rather than sell gas in the US, while the ultimate success or failure of the development of the country's unconventional gas resources will also have a key bearing on the outcome. This issue, as well as the impact of the possible price reaction in European and Asian markets, is discussed in Section 4, and so at this stage the one conclusion that can be reached is that the physical potential for US LNG exports by 2020 is approximately

\footnotetext{
${ }^{56}$ BP (2012)
} 
100mtpa, in addition to the 20-30mtpa that could come from Canada, although the practical outcome is likely to be constrained by the realities of commercial (and possibly political) forces. 


\section{The Political Debate over LNG Exports}

Although the commercial motivation for exporting gas from both the US and Canada is strong and a number of projects have been proposed, the political reaction to the potential development of an LNG export business is somewhat different in both countries. In Canada there appears to be uniform support at both a federal and a regional level for the growth of an industry that can provide clear economic benefits and which would appear to offer little threat to domestic consumers. The reaction in the US, however, is much more ambiguous and politically sensitive as a balance is sought between the clear advantages for US exporters of expanding global trade and further developing the domestic gas industry and the potential economic risks of higher domestic gas prices and the perceived environmental risk of encouraging further development of unconventional gas resources. As a result of the sensitive nature of the debate it is very unlikely that any definitive decisions will be taken before the US Presidential election in November 2012, but as discussed below it would then seem likely that a positive decision to begin the sanctioning of LNG export projects will be made in 2013.

Canada keen to replace pipeline exports to the US with LNG exports to Asia

Although some concerns have been raised about the impact of LNG exports on Canada's long-term energy security, the plans to develop a number of projects to send gas to Asia have received broad political support. Although some of this support is based on the benefits to specific provinces, with for example the Premier of British Columbia Christy Clark seeing LNG exports as a "major economic opportunity and job creator" for the country's westernmost province, ${ }^{57}$ Canada also has a macro-economic incentive to develop a new source of export revenue. Historically Canada has been a large exporter of gas to the US via various trans-continental pipelines, selling over $100 \mathrm{bcma}$ to its southern neighbour throughout much of the early part of the 2000s (offset to a small extent by some reciprocal gas imports). ${ }^{58}$ However, since the surge in US gas production from unconventional sources began in the middle of the last decade, both Canada's net exports, and its overall gas production, have fallen significantly.

Figure 4 shows Canada's gas production and its net exports since 2007. In that year Canada produced 183bcm of gas, a level that had been consistent for the entire period since 2000 when it had total output of $182 \mathrm{bcm}$. However, from 2007 to 2011 production fell by $12 \%$ to

\footnotetext{
${ }^{57}$ Reuters, 15 May 2012, “Two more North American LNG export projects planned”, Calgary

${ }^{58} \mathrm{BP}(2005)$
} 
$160 \mathrm{bcm}$, with the volumes lost being consistent with the decline in the country's net exports of gas, which fell by $36 \mathrm{bcm}$ over the period, slightly offset by a $14 \mathrm{bcm}$ increase in domestic demand. With a number of commentators now forecasting that the US could become selfsufficient in gas, and even oil, ${ }^{59}$ this trend is set to continue, with the distinct possibility of Canadian exports to the US reaching zero by 2035 according to the latest forecast by the EIA. $^{60}$

Figure 4: Canadian Gas Production and Net Exports (to US), 2007-2011

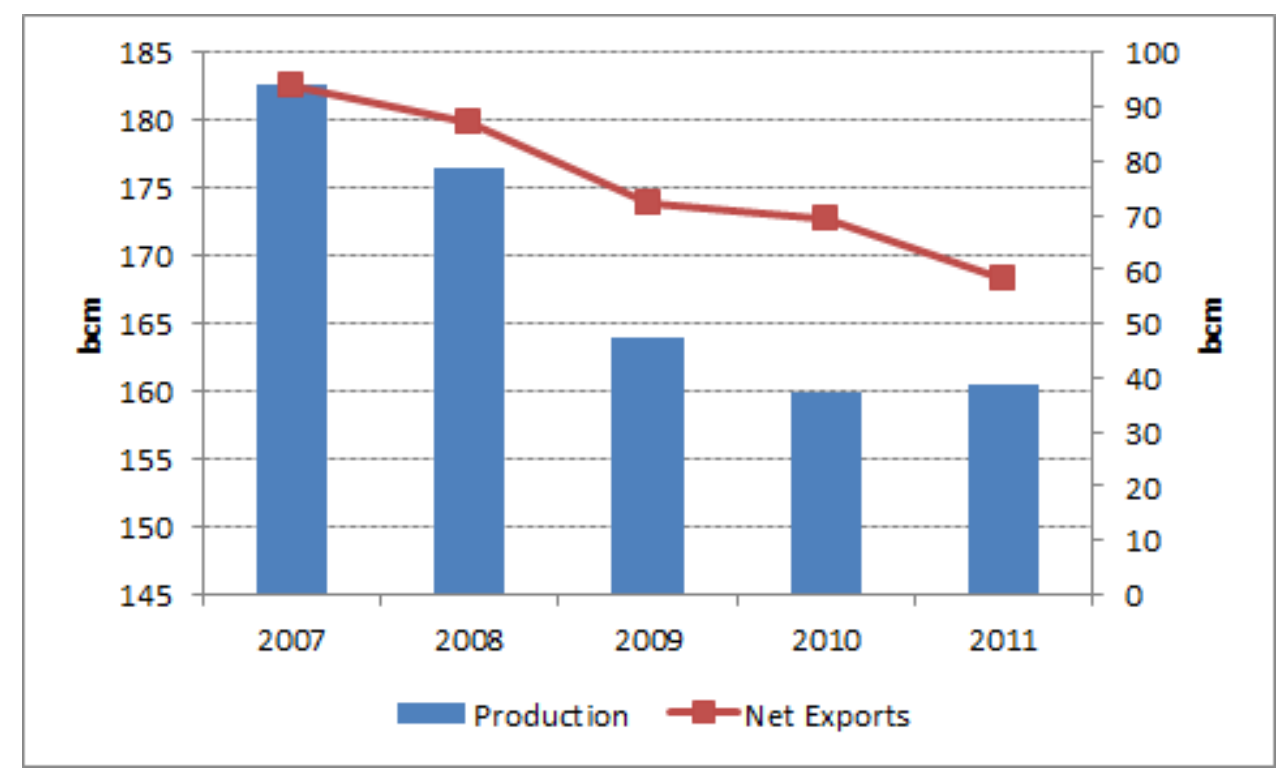

Source: BP (2012)

As a result of this decline in gas exports to the US, the Canadian Administration has made it clear that it is looking both for alternative gas markets and for partners to help it exploit its unconventional and conventional gas reserves for export. Prime Minister Steven Harper has stated that Canada is keen to diversify its energy exports "to countries that want to buy them", ${ }^{61}$ and during a visit to China in February 2012 he confirmed the potential for strong energy links between the two countries. A broad agreement was reached on the terms for reciprocal direct investment, with a particular focus on the sustainable development of natural resources in Canada and corresponding co-operation on providing access to Chinese energy markets, ${ }^{62}$ and Harper confirmed in a speech at the end of his trip that "we are an emerging

\footnotetext{
${ }^{59}$ Financial Times, Jan 18 2012, "US on path to energy self-sufficiency”.

${ }^{60}$ EIA World Energy Outlook 2012, “US Natural Gas Supply, Disposition and Prices Reference Case”, Washington

${ }^{61}$ Globe and Mail, Toronto, 26 July 2012, “A dramatic bid, a strategic response”.

${ }^{62}$ Financial Post, 8 Feb 2012, “Canada, China tighten trade ties”.
} 
energy superpower. We want to sell our energy to people who want to buy our energy. It's that simple. China needs energy and Canada has natural resources to sell.”, 63

Canada's commitment to China and also to other Asian markets is further underlined by the partnerships that are now being formed to develop the country's oil and gas for delivery to Asian markets. In May 2012 PetroChina announced its involvement in the LNG Canada project close to Kitimat in British Columbia in partnership with Shell Canada and another Asian LNG purchaser, Kogas from South Korea ${ }^{64}$. Subsequently CNOOC has announced a bid for Nexen Energy, a Canadian exploration and production company with exposure to huge tracts of oil sands licences in Canada, as well as assets in the US and the North Sea. In Canada the political reaction to the deal has been cautiously positive, with concerns about giving away control of domestic assets likely to be outweighed by the potential for strengthening economic ties with the fastest growing market for energy in Asia. ${ }^{65}$ If approved, the bid would add another Asian company to a growing list of Asian investors in Canada's natural resource sector, including Petronas (likely purchaser of shale gas company Progress Energy in British Columbia) ${ }^{66}$ and Mitsubishi, who bought $40 \%$ of Encana's Cutbank Ridge gas property in February 2012 with a plan to export any gas production as LNG. ${ }^{67}$ In conclusion, Canada appears to be both economically and politically committed to using its natural resources, and in particular gas, as a vehicle for strengthening trade ties with Asia and will therefore support any LNG export plans to further this strategy and to replace lost export revenues from declining gas sales to the US.

US struggling to balance economic and trade incentives with domestic price and environmental concerns

The collapse in US gas prices to a range of \$2-3/mmbtu for large parts of H1 2012 has caused a significant divergence from gas prices in Europe and Asia, where the impact of oil-linked contracts has seen prices reach a range from \$10-18/mmbtu. Even after liquefaction and transport costs this price gap has created a huge incentive for producers of gas in the US, as well as consumers in Europe and Asia, to seek ways to arbitrage the price difference, and as such the commercial and economic logic for LNG exports from North America seems to be incontrovertible in a free trade environment. However, lobbying from industrial companies,

\footnotetext{
${ }^{63}$ CTV News, 10 Feb 2012, "Harper mixes oil and human rights in China speech".

${ }^{64}$ PetroChina Press Release, 16 May 2012, "PetroChina and International Energy Firms Launch LNG Canada”.

${ }^{65}$ The Vancouver Sun, 29 July 2012, "Plenty for Canada to ponder in China's bid for Nexen".

${ }^{66}$ Reuters, 27 July 2012, "Petronas raises Progress Energy offer after rival bid”.

${ }^{67}$ Reuters, 17 Feb 2012, “Encana finds shale gas partner in Mitsubishi”.
} 
power generators and consumer groups in the US, who are currently enjoying the benefits of lower gas prices and fear that these will be lost in a scenario with unconstrained gas exports, has turned the issue of US LNG exports into a political one in which a number of potentially conflicting interests need to be balanced.

A number of studies have attempted to analyse the impact of potential US LNG exports from a geo-political, economic and commercial perspective. ${ }^{68}$ The initial, and fairly obvious, conclusion from all the reports is that gas exports could bring a beneficial macroeconomic impact, with these being quantified by Levi ${ }^{69}$ as a gain in economic output of $\$ 4$ billion per annum from overseas sales of increased natural gas production, an increase in export revenues of $\$ 20$ billion per annum and the creation of 8,000 jobs in near-term construction as well as 60,000 long term jobs across the natural gas production and supply chain. From a geo-political perspective, it is also noted that allowing gas exports from the US could help to alleviate the somewhat opaque and politically entangled nature of the global gas market and could give the US increased bargaining leverage in negotiations with other important gas exporting countries in the Middle East as well as Russia. Furthermore, the banning of gas exports would go completely against the US' free trade principles and could cause major ruptures with NAFTA and the WTO as well as giving leverage to other countries looking to limit the exports of other raw materials. ${ }^{70}$

However, those lobbying against the approval of LNG exports bring a number of arguments to bear, including the potential impact on gas consumers in the US (primarily through the impact of higher gas prices), the possible environmental impact of encouraging higher gas production (especially from unconventional sources), the risks to US oil security and the impact on climate change. In particular the IECA (Industrial Energy Consumers of America), an industrial lobby group, has been very vocal in its calls for the US government to consider the price impact of gas exports and the potential erosion of the US's energy advantage, ${ }^{71}$ and has also been very critical of various of the reports that have argued in favour of exports

\footnotetext{
${ }^{68}$ Key reports include “The Effect of Increased Natural Gas Exports on Domestic Energy Markets”, EIA, January 2012; “A Strategy of US Natural Gas Exports”, Michael Levi, Brookings Institute, June 2012; "Made in America: The economic impact of LNG exports from the United States”, Deloitte Center for Energy Solutions, June 2012

${ }^{69}$ Levi (2012).

${ }^{70}$ For example the US would find it difficult to argue against China's mineral export quotas if it had imposed limits on gas exports.

${ }^{71}$ Financial Times, Jan 10 2012, “US Industry hits at LNG export plan”.
} 
being permitted. ${ }^{72}$ However, although the case against LNG exports appears to have emotive force and to carry superficial logic (higher gas prices will harm US consumers, especially if US gas supplies from unconventional sources do not meet expectations), it would appear from most analysis that the underlying reality argues against this view.

In particular the argument against LNG exports would appear to be undermined by the fact that much of the analysis concerning gas prices indicates that the long-term price impact of adding exports to domestic demand would be relatively low. The EIA was specifically tasked in 2011 with analysing the potential impact of gas exports on domestic gas prices under various supply and demand scenarios, and its report published in January $2012^{73}$ concluded that, although the immediate impact of the introduction of exports would be to see relatively sharp price rises (14-36\% above a reference case), in the long-term the price impact would be largely mitigated by normal market-balancing.

The EIA study initially focusses on the impact of various levels of exports on a reference case outlook, ${ }^{74}$ with four scenarios for exports examined:

1. Low/Slow - 6Bcf/d (62bcma) introduced at a rate of 1Bcf/d (c.10bcma) per annum

2. Low/Rapid - 6Bcf/d (62bcma) introduced at a rate of 3Bcf/d (c.31bcma) per annum

3. High/Slow - 12Bcf/d (124bcma) introduced at a rate of $1 \mathrm{Bcf} / \mathrm{d}$ (c.10bcma) per annum

4. High/Rapid - 12Bcf/d (124bcma) introduced at a rate of 3Bcf/d (c.31bcma) per annum

\footnotetext{
72 "Rebutting the IECA attack on Levi’s Natural Gas Exports Study", sourced from: http://www.hamiltonproject.org/blog/rebutting_the_ieca_attack_on_levis_natural_gas_exports_study/ ${ }_{73}^{73}$ EIA (2012)

${ }^{74}$ Reference case as published in the EIA Annual Energy Outlook 2011
} 
Figure 5: EIA Scenarios for US Gas Exports

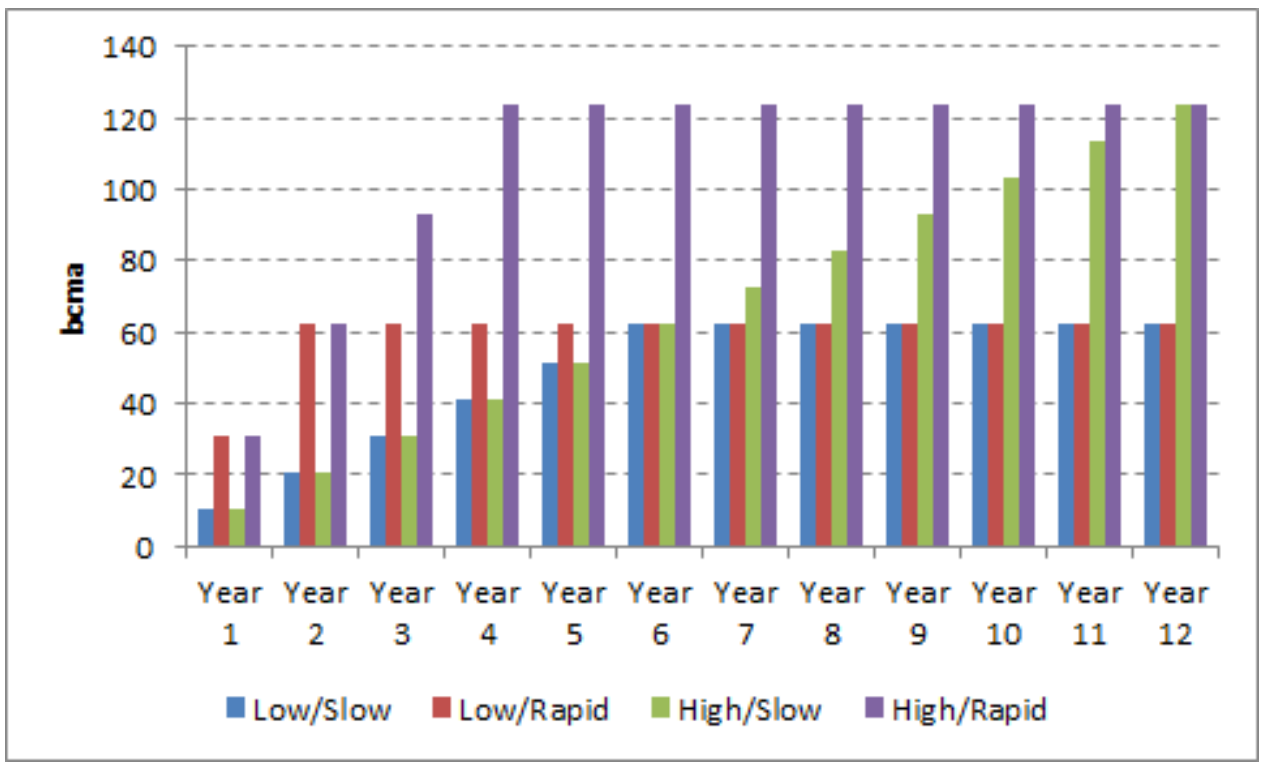

Source: EIA (2012)

The EIA reference case envisages average net imports of gas of almost 1.3bcf/d (c.13bcma) from 2015-2035 and an average Henry Hub price of $\$ 5.80 / \mathrm{mmbtu}$, with total US gas production reaching $745 \mathrm{bcma}$ by the end of the period, of which $345 \mathrm{bcma}(47 \%)$ will be contributed by shale gas. The impact of new gas exports in this case is shown in Figure 6, with the low/slow case creating a 10\% increase in prices over the period and the high/rapid case creating an average price increase of $21 \%$.

Figure 6: Price Impact of Exports on EIA Reference Case Gas Price

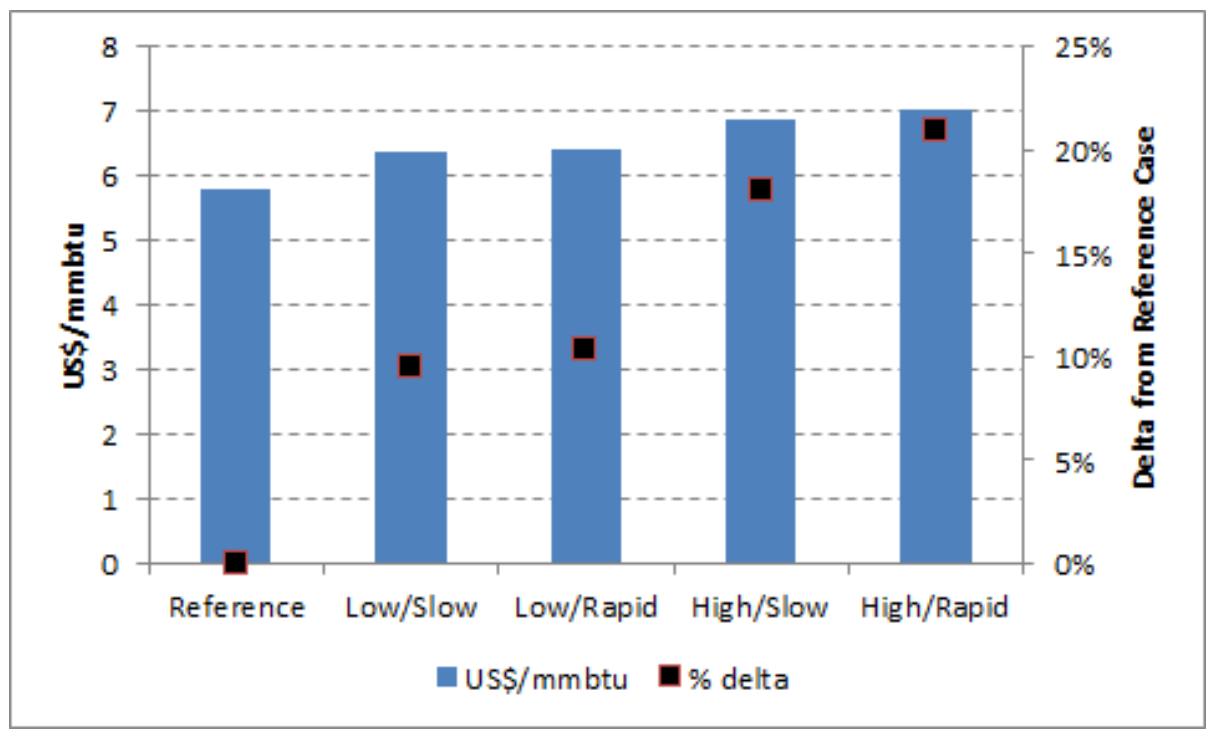

Source: EIA (2012) 
However, the shape of the price growth over the period is also important, as it helps to explain why the issue of gas exports is so potentially significant in a political context. In all the scenarios, and especially in the cases of rapid development of exports, an initial price spike is anticipated prior to a re-adjustment relative to the base case as the market adapts to the extra demand for US gas (Figure 7). This re-balancing is seen as occurring through two main drivers, firstly reduced demand as consumers adjust to higher prices and also through increased supply, as higher prices and a new market opportunity encourages gas producers to increase output and to exploit new resources.

Figure 7: Difference in gas price relative to Reference Case under different gas export scenarios

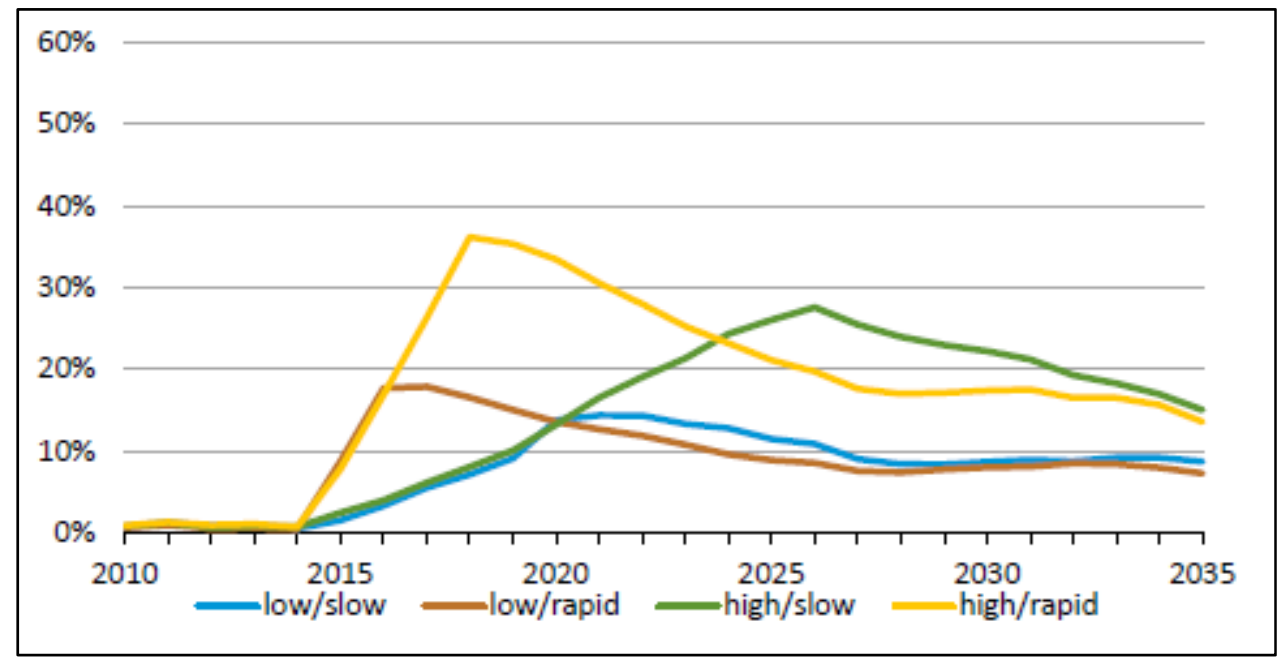

Source: EIA (2012)

However, this second driver of price re-balancing prompts an additional question over the availability of gas resources in the US and the impact of various production scenarios. A study by INTEK, sponsored by the EIA, in July 2011 suggested that the shale gas resources in twenty already discovered plays in the US could total 750Tcf (21Tcm), ${ }^{75}$ sufficient if fully exploited to cover more than 30 years of current US consumption on their own, irrespective of the country's 8Tcm of existing proved conventional gas reserves. ${ }^{76}$ However, the relative immaturity of this new source of gas supply means that it is difficult to estimate both the total recoverability factor for each play and the ultimate recovery factor for each shale gas well. As a result the estimates of gas production from the US shale gas resource could be significantly over- or under-estimated. The EIA has therefore also analysed the impact of higher or lower shale gas production on its price scenarios to create a more intricate matrix of estimates based

\footnotetext{
${ }^{75}$ EIA (2011)

${ }^{76}$ BP (2011)
} 
on export scenarios and production. The results of the analysis are shown in Figure 8 and indicate the relatively significant impact that different production outcomes could have. In the Low Shale Scenario the estimated ultimate recovery per shale gas well is assumed to be $50 \%$ lower than in the Reference Case, while in the High Shale Scenario it is assumed to be $50 \%$ higher, and the difference in price impact on the Reference Case is to create a price range of $\$ 4.41-8.12 / \mathrm{mmbtu}$ around the base case of $\$ 5.81 / \mathrm{mmbtu}$. In the most extreme case (the high/rapid export case) the US gas price could rise as high as $\$ 9.77 / \mathrm{mmbtu}$ in the Low Shale Scenario, although it could also be as low as $\$ 5.77 / \mathrm{mmbtu}$ under the same export assumption if shale gas production surpasses expectations.

\section{Figure 8: The Impact of Different Shale Gas Production Scenarios on US gas prices}

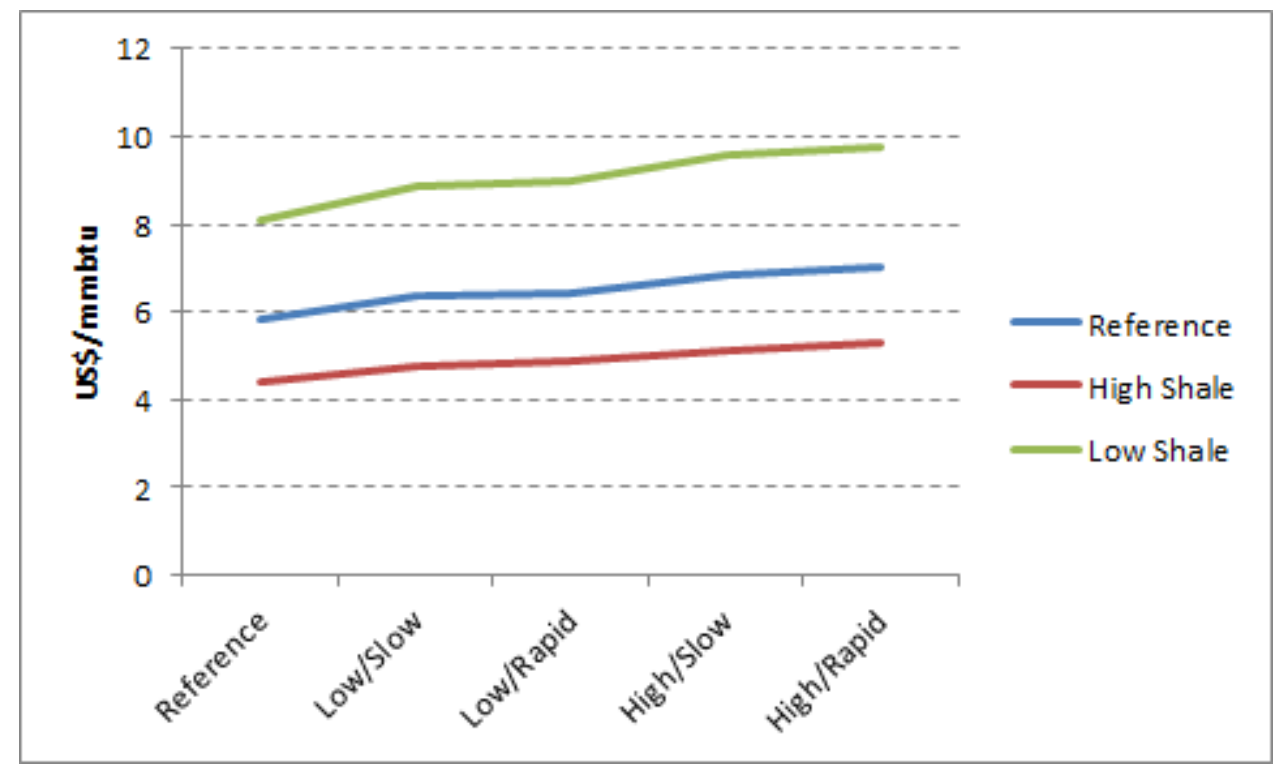

Source: EIA (2012)

The broad range of outcomes provides a clear political dilemma, especially ahead of the US presidential elections in November 2012. No candidate will be prepared to endorse a strategy that risks seeing gas prices triple from current levels in a low shale production scenario, and as a result a definitive decision on gas exports is not expected until 2013 at the earliest. Further complications are added by the fact that the anti-export lobby is arguing strongly on a number of other issues, including environmental impact, climate change, US oil security and the distributional impact of possible higher gas prices as a result of exports.

From an environmental point of view the key debate is about the impact of unconventional drilling. In a scenario where gas exports encourage higher production and therefore greater drilling activity, the potential harm that could be done to water resources and/or local 
geological conditions (as a result of earthquakes) is a clear worry, especially as even the current levels of drilling are attracting public concern. There is no immediate answer to this problem as numerous scientific studies are currently continuing to assess the possible correlation between the fraccing of wells and seismic activity and the risk of water contamination from drilling residue, ${ }^{77}$ and although commercial drivers will likely lead to a positive outcome for gas companies the risk remains that drilling could be restrained in some areas and that politicians will be nervous about making any commitment until full results of the scientific tests are received.

With regard to climate change, the arguments appear to be more balanced and therefore provide less risk to gas exports. On the negative side it is argued that higher domestic prices resulting from gas exports would reduce the incentive for power generators in particular to switch from coal to gas, thus increasing carbon emissions. However, there are two strong countervailing arguments to this, namely that gas exports can encourage greater gas use overseas by lowering prices in Europe and Asia, and also that the current low gas prices in the US are forcing coal producers to export relatively cheap coal from the US, thus encouraging greater coal use outside the US at present. As a result, although gas exports might result in higher domestic coal use it would also have an equal and opposite effect in overseas markets, thus effectively neutralising any harmful impact.

Concerning oil security the debate centres on the potential use of natural gas in the US to provide a transport fuel, thus reducing US demand for oil and therefore the country's exposure to high oil prices and imports from potentially hostile countries. Again, this is a topic of much on-going debate, with both the economic and geo-political issues being contested. From an economic perspective, although increased gas use for transport could reduce oil dependency and exposure to high oil prices, the cost of new infrastructure for CNG and/or LNG vehicles could offset much of the short-term gain and would mean that the benefits would be very similar to those of allowing gas exports. From a geo-political perspective, many of the countries that export oil to the US are also, or are set to become, large gas exporters and so although a ban on US gas exports might dent their oil revenues and influence it could also encourage a greater presence for these same countries in the gas market. Although the impact on the US might be reduced, the global difference (which is also

\footnotetext{
${ }^{77}$ For example "Water Pollution Risk Associated with Gas Extraction from the Marcellus Shale”, Rozell D. \& Reaven S, published in Risk Analysis, August 2012, and "Induced Seismicity Potential in Energy Technologies”, US National Research Council, summarised in Scientific American, 15 June 2012,” Fraccing can cause earthquakes, but so can oil and gas extraction.”
} 
a key concern to the US) would be relatively small. Overall, then, the possible impact of gas usage for transport in the US is likely to have minimal impact on the US' exposure to the oil market and to the major energy exporting nations.

A final economic argument, and one which again points to the overall debate being pushed back beyond the presidential elections, is that lower income consumers in the US will be disproportionately hit by the impact of gas exports. This is because the share of energy costs in their overall budget is greater than that for higher income consumers, and therefore any increase in gas prices will hit them harder. Having said that the numerical impact is relatively small, estimated at $\$ 50$ per annum for each $\$ 1$ rise in gas prices, ${ }^{78}$ but the issue is clearly another sensitive one in a political context and could therefore be another delaying factor.

In overall conclusion, although the potential impact of future US gas exports on internal US gas prices would appear to be relatively small and the economic benefits would appear to outweigh the negatives, there is enough uncertainty and potential downside for important parts of the US electorate to make the issues very sensitive politically. From a price perspective it would seem that in a base case scenario even an aggressive export strategy that could see $120 \mathrm{bcma}$ of gas exports introduced over four years would only result in an average extra price increase between 2015 and 2035 of 21\%; the short term impact would be higher but would be smoothed out in the longer term. More critical, however, would be the impact if the US shale gas resources failed to produce as much gas as anticipated, which could result in an average price of almost $\$ 10 / \mathrm{mmbtu}$ across the period compared to $\$ 5.81$ in the reference case $^{79}$. Although other studies have concluded that in fact the price impact of exports could be much lower than this (for example a recent Deloitte analysis ${ }^{80}$ concluded that exports would only lead to an average $2 \%$ increase over an average reference price of $\$ 7.09 / \mathrm{mmbtu}$ in the period 2016-2035), the risks of a negative outcome combined with other arguments brought by the anti-export lobby on the environment, oil security and energy costs will mean that any decision on exports will be delayed until 2013, after the 2012 presidential election cycle.

As far as the ultimate outcome is concerned, it is likely to be driven as much by commercial reality as political will. If prices for domestic gas in the US rise either as a result of exports being allowed or as a result of disappointing shale gas results, the incentive for gas producing

\footnotetext{
${ }^{78}$ Levi (2012)

${ }^{79}$ EIA (2012)

${ }^{80}$ Deloitte (2012)
} 
companies to export rather than sell gas domestically will be reduced, thus providing a natural market balance and a ceiling for export sales from the US. Alternatively a sharp fall in the oil price could also make US gas exports less competitive in markets where gas is currently priced in relation to the oil price. Indeed this is, of course, the free market argument and one that is likely to prevail once the political pressure of the election process has been reduced. The next step in the process will be the production of a second report by the Office of Natural Gas Regulatory Activities which is due in the autumn of $2012,{ }^{81}$ and once the presidential election has been completed this report can then form the basis for a rational debate on the topic which can cover the full potential impact of increased interaction between US and global markets, as discussed in the following section.

${ }^{81}$ Reuters, 27 June 2012, “As Congress looks away, US tiptoes towards exporting a gas bounty”. 


\section{How Significant will North American LNG Exports be in the Global Gas Market?}

Answering the question what will be the potential impact of North American LNG exports on global gas markets is complicated because the flow of any gas from the US and Canada will interact with other supply and demand forces that will sum to create an overall market reaction. At a high level, the potential impact would appear to be potentially very large. During 2011 331bcm of LNG was exported/imported across the globe, ${ }^{82}$ with the majority (221bcm) arriving in Asia while Europe and Eurasia $(91 \mathrm{bcm})$ was the second largest purchaser. In this context, the export of 124bcma in the EIA's high US export case would account for almost 38\% of this total trade, while even the lower export assumption (62bcma) would account for around 19\%. If one considers the total possible output from all the projects that have been approved, have requested approval or have been proposed in the US and Canada, then their total potential output of 250bcma would equate to more than two thirds of current global LNG trade and could theoretically supply all of Asia's 2011 LNG demand. From a US perspective, this would also mean that the country would be exporting almost $40 \%$ of its 2011 production, and this potential outcome has been the clear driver behind the political concern over the possibility of rising domestic gas prices.

However, the enormity of these figures themselves underlines the fact that, as highlighted by Rogers, ${ }^{83}$ the data cannot be considered in a static fashion but as part of a dynamic global market place that will react to the entry of US exports, both in terms of Asian (and European) supply, demand and prices and also in terms of a balancing reaction in the US. Furthermore, the market reaction will also differ in the short and long term, depending upon the speed at which consumers and producers are able to respond to the changing market dynamics. As identified by Medlock (2012) ${ }^{84}$ the elasticity of supply in particular, as well as the demand response, in both the US and in regions that could buy US exports will determine both where an equilibrium price is established and the ultimate volume of LNG exports from North America. The granting of export licences from facilities in both the US and Canada does not establish the amount of gas that will be exported but the amount of gas that could be exported, if market conditions provide an arbitrage opportunity. Therefore to fully understand the short and long-term consequences of North American LNG exports it is important to

\footnotetext{
${ }^{82}$ BP (2012)

${ }^{83}$ Rogers (2012)

${ }^{84}$ Medlock III, K, B, 10 Aug 2012, “US LNG Exports: Truth and Consequence”, James A. Baker III Institute for Public Policy, Rice University, Texas
} 
consider the short and long-term elasticity of supply to those markets and its consequent ability to deal with changes in demand and price.

The theoretical impact of the elasticity of gas supply in the US and Asia

In its analysis of the price impact of LNG exports on gas prices in the US the EIA analysed two fixed levels of export sales, 6bcf/d and 12bcf/d, and concluded that although the longterm price impact in the US would be relatively low as producers adapted to the new level of demand, the short-term impact could be relatively high because producers might not be able to react swiftly enough. ${ }^{85}$ However, this latter conclusion again highlights the dynamic rather than static nature of the process, and emphasizes that the impact of potential US LNG exports should be described in a more interactive manner, taking into account the possible changes in both the domestic US market and also in the foreign markets where the LNG could be sold. Essentially these dynamics are described by theories of international trade ${ }^{86}$ and it may be useful to discuss the broad outline of these theories and how they might relate to US LNG exports before applying specific data to the analysis. ${ }^{87}$

Figure 9: The Impact of Elasticity on Prices in Domestic and Foreign Markets assuming Import/Export Trade

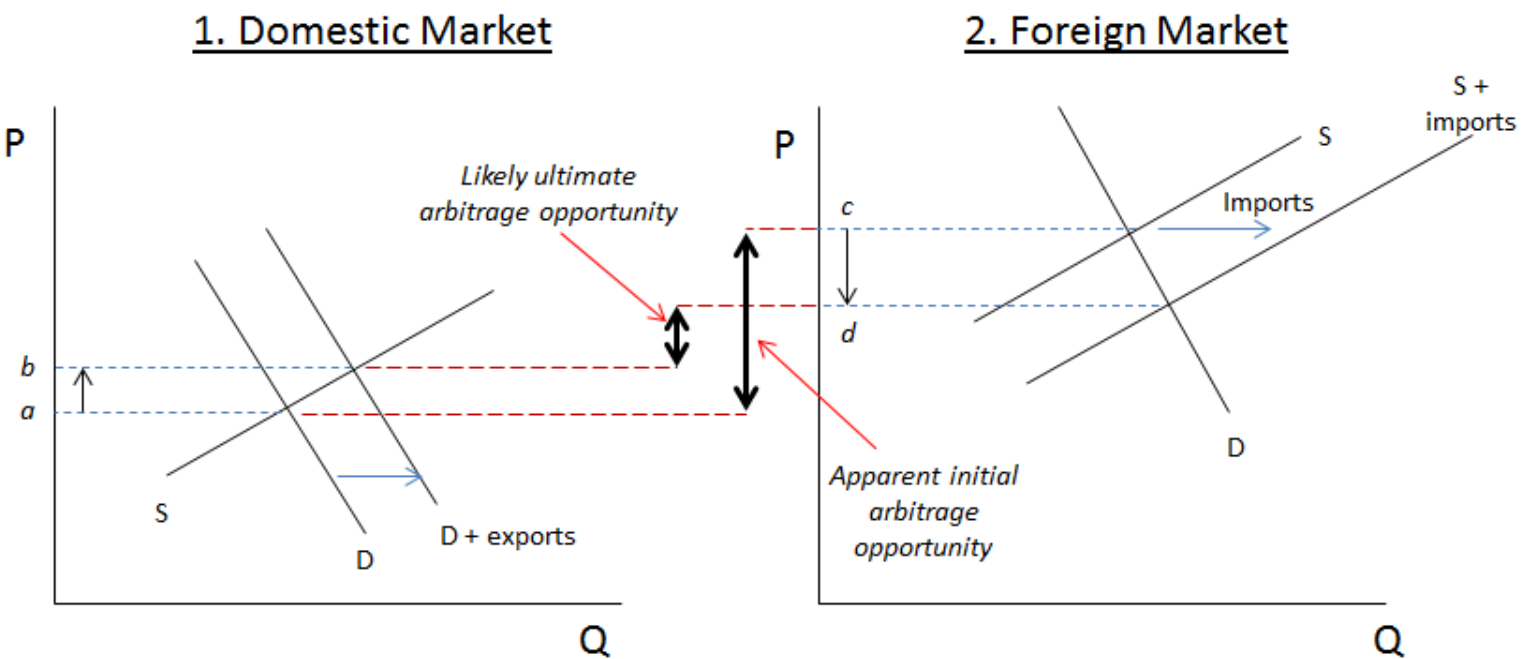

Source: Adapted from Samuelson (1976) and Medlock (2012)

NB: In the graphs above $P=$ Price, $Q=$ Quantity, $D=$ Demand, $S=$ Supply and $a, b, c$ and $d$ represent various price levels

\footnotetext{
${ }^{85}$ EIA (2012)

${ }^{86}$ Samuelson (1976)

${ }^{87}$ See: Medlock (2012) for a full description of this analysis from a US perspective
} 
Initially, prior to any cross-border trade occurring, the domestic market (in this case the US) and the foreign market (the potential buyers of US LNG) function separately and as a result supply and demand in each region (domestic and foreign) set a price for gas that is specific to that area. In the example of the domestic market shown in Figure 9 that price is set at $a$ in Graph 1 and in the case of the foreign market it is set at $c$ in Graph 2. The price differential between $a$ and $c$ provides a clear apparent arbitrage opportunity and an incentive for producers in the domestic market to try and export their product into the foreign market. Of course this is an exact analogy of the situation in the US gas market at the current time, with producers looking to export their gas into the higher price environment on offer in Asia and Europe.

Once trade is introduced, however, the dynamics of the market and the elasticity of the supply curves in the two regions come into play. As exports are allowed from the domestic market, so the effective demand line moves to the right up the supply curve, increasing the price of gas in the domestic market (from point $a$ to point $b$ ). The extent of the price impact will reflect the slope of the supply curve, with a steeper slope having a great price impact. Put another way, the greater elasticity there is in the supply curve (i.e. the shallower the slope) the lower the price impact will be, and therefore one key consideration in analysing the price impact of US LNG exports on both the domestic and foreign markets concerns the supply curve of conventional and unconventional gas production in the US.

In the foreign market the opposite reaction takes place. As imports are introduced the supply curve moves to the right down the demand curve, lowering the price of gas in the region (from point $c$ to point $d$ ). Again, the precise impact of the introduction of imports will depend upon the slope of the supply curve into the foreign market and the place that imports take on the supply curve. The interaction between the two markets then culminates with the rising price in the domestic market $(b)$ converging towards the falling price in the foreign market $(d)$. These price levels will continue to converge until the difference between them is accounted for by the cost of exporting the gas from one to the other (in this case the cost of liquefaction, transport and regasification). Once this point is reached the arbitrage opportunity will have ended and there will be no incentive for further exports to take place. In conclusion, the theory underlines the point that although politicians in the US may be concerned over possibly granting too many export licences for multiple LNG facilities that could export up to one third of the country's current gas output, in reality it is the interaction of the domestic and foreign markets and the relative elasticity of the supply curves in the two 
regions that will decide the ultimate volumes that are traded. Political decisions will make potential export volumes available, but will not necessarily lead to the physical sale of US gas into overseas markets.

However, as highlighted in the EIA analysis, ${ }^{88}$ the impact of US LNG exports on prices needs to be considered in both the short and long term, particularly in an industry where the investment process is relatively long and therefore where the short-term elasticity of supply can be low even if the longer term elasticity is high. This effect can perhaps be best explained by using one more theoretical chart and applying the actual circumstances in the US and Asian gas markets over the past 12-18 months to illustrate the point.

Figure 10: The Potential Impact of the Relative Elasticity of Supply on Prices in Domestic and Foreign Markets

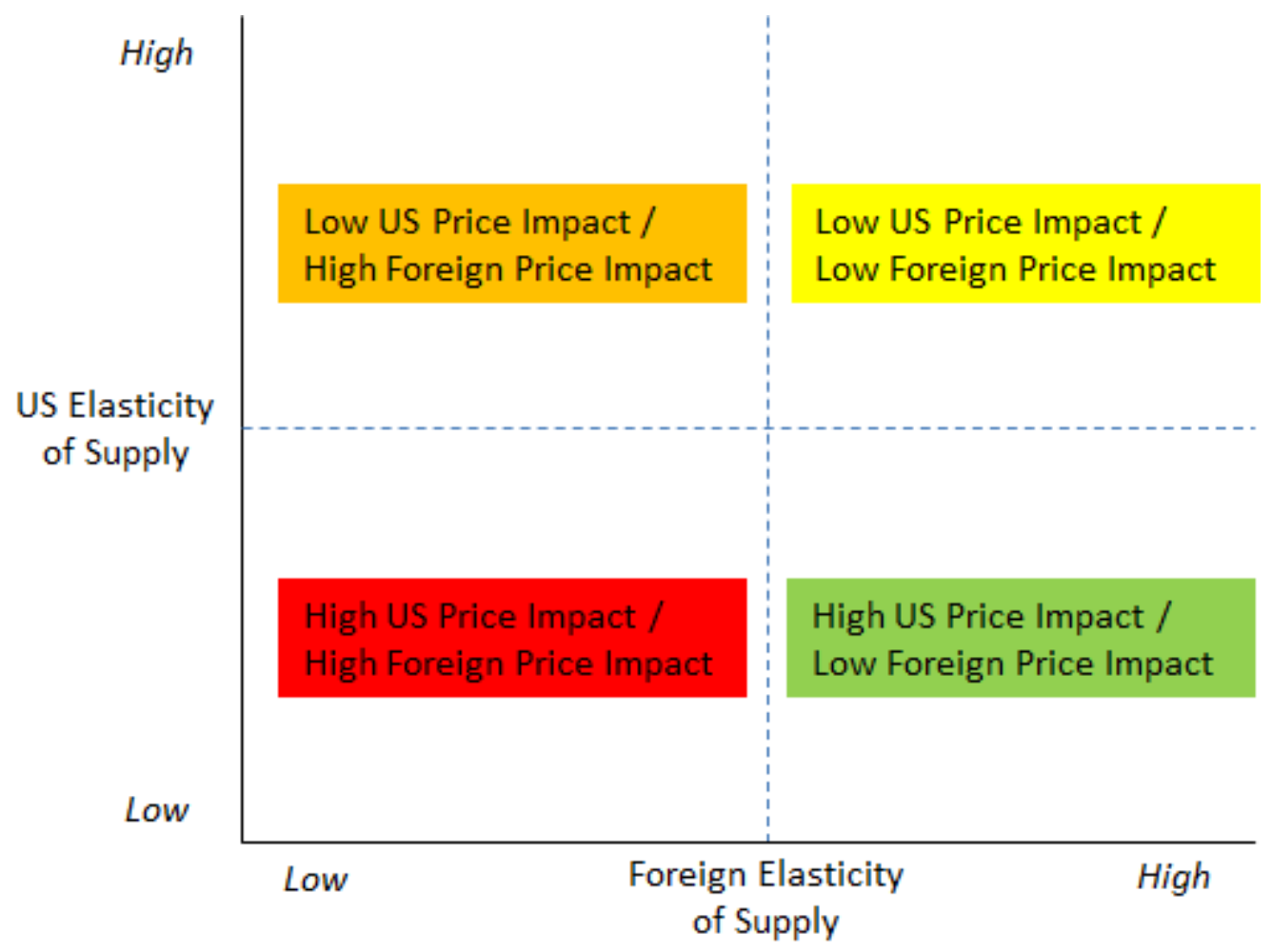

Source: Adapted from Medlock (2012)

As discussed above, if the slope of the supply curve in a region is steep (in other words if elasticity of supply is low) then the price impact of any change in supply will be high. Conversely if the gradient is shallow (elasticity is high) then the price impact will be low. Figure 10 above captures the different scenarios for the domestic (US) and foreign markets

${ }^{88}$ EIA (2012) 
depending upon the relative supply elasticity in the markets. In a situation where elasticity is high in both markets, then the price impact of any shift in supply or demand will be relatively low in both (top right quadrant), whereas if the elasticity is low in both markets then the price impact will be high in both (bottom left quadrant). Clearly if the elasticity in the markets is different then the price impact will also differ, as shown in the two other quadrants.

Interestingly the bottom left quadrant in Figure 10 helps to describe the short-term price movements in and price disparity between the US and Asian markets over the past 12-18 months. In the US the winter of 2011/12 was one of the warmest on record ${ }^{89}$ and coincided with a continuing increase in gas production that had been initiated from upstream investment over the previous two to three years. As gas demand for winter heating fell to far-below normal levels producers were not able to react fast enough (in other words short-term elasticity of supply was low) and gas prices reacted sharply with a $50 \%$ decline between September 2011 and April 2012. ${ }^{90}$ Since then the market has started to rebound, with demand for gas in power generation rising at the expense of coal and gas-focused rig counts declining as producers attempt to reduce supply, and as a result the Henry Hub benchmark price has now recovered to above $\$ 3 m m b t u$ again. Nevertheless the high price impact of short-term low elasticity of supply is clear.

Meanwhile in Asia an opposite effect has been caused by the Fukushima disaster in Japan in March 2011. Since the disaster and the subsequent shut down of almost all of Japan's nuclear power generation plants demand for LNG has increased sharply as Japanese power companies have been forced to seek alternative fuel inputs to keep the country's electricity supply running. In July 2012 Japanese companies imported 5.1Mt of LNG, 15\% more than in the corresponding period in 2011 and 40\% more than in July 2010, ${ }^{91}$ before the Fukushima disaster. At the same time gas demand in China has also continued to increase rapidly, rising by 10.5\% between July 2011 and July 2012. ${ }^{92}$ However, short-term supply to the Asian market was not elastic enough to be able to cope with this unforeseen short term boost in demand, and as a result a significant price spike has occurred, with the Japanese LNG spot price rising by more than 40\% between March 2011 and May 2012.

\footnotetext{
${ }^{89}$ Reuters, 1 Feb 2012, "Warm winter creates winners and losers in US economy”.

${ }^{90}$ Gas price data from Energy Intelligence Group

${ }^{91}$ Interfax Gas Daily, 13 Aug 2012, “Japan's utilities increase LNG imports in July”.

92 Interfax Gas Daily, 20 Aug 2012, “China's gas consumption rises by 10.5\% in July”.
} 
As a result of the combined low short-term elasticity of supply in both the US and Asian markets, sharp price movements in opposite directions have led to the wide current price disparity between the two markets. Supply in the US could not be reduced fast enough and as a result the gas price fell to below $\$ 2 / m m b t u$ in April 2012, while supply to Asia has not been able to rise fast enough and as a result the spot LNG price has risen as high as $\$ 18 / \mathrm{mmbtu}$. However, this price action is clearly being driven by short term phenomena, the impact of which is likely to be reversed over time. Indeed the rebound in the US gas price has been noted above, while spot LNG prices in Asia have now fallen back to around $\$ 13 / \mathrm{mmbtu}{ }^{93}$ leading to the conclusion that even without US LNG exports the global gas market is already trending back to an equilibrium in which there is less disparity in prices between different regions.

In the face of this volatility in gas prices over the past 18 months it is perhaps important to make the fairly obvious statement that decisions about investment in North American gas export projects need to be taken based on the long-term outlook for gas markets and the place that US and Canadian LNG can take on the supply curve rather than in reaction to a shortterm price gap that has been exaggerated by temporary phenomena. The clear long-term choice for producers will be whether to sell their gas into the North American market, or whether to incur the cost of liquefaction and transport to sell it into a foreign market. As a result, the future price dynamics of US gas prices are of particular importance, as are the costs of creating and transporting LNG.

In terms of the US market, it is widely believed that the current low level of gas prices does not reflect the long-run marginal cost of supply that must be achieved if producing companies are to avoid shutting in production or going bankrupt. A recent study from MIT estimated that the breakeven price for the US shale resource base is between $\$ 4-8 / \mathrm{mmbtu}^{94}$ while Michelle Foss ${ }^{95}$ calculates an average breakeven cost for upstream operators in the US during the period 2007-2010 at \$6/mmbtu. A report by Deloitte’s “Centre for Energy Solutions” estimates that 1200Tcf (34Tcm) of gas in the US would be economically available for production at this same $\$ 6 / \mathrm{mmbtu}$ level, ${ }^{96}$ while analysis from the Brookings Institute assumes a price of $\$ 5 / \mathrm{mmbtu}$ as a level at which sufficient gas can be produced profitably in

\footnotetext{
${ }^{93}$ World Gas Intelligence, 22 Aug 2012, "Spot LNG: Prices pick up in Asia, remain steady in Europe”.

${ }^{94}$ MIT, 2011, “The Future of Natural Gas”, sourced from http://web.mit.edu/mitei/research/studies/natural-gas2011.shtml

${ }^{95}$ Foss (2011)

${ }^{96}$ Deloitte (2012)
} 
the US. ${ }^{97}$ Perhaps the most thorough recent analysis, however, has been conducted at Rice University in Texas, where a full cost curve analysis has concluded that a Henry Hub price in the range $\$ 4-6 /$ mmbtu over the next two decades will be sufficient for the production of the identified shale gas resources in the US, which are set to provide the majority of any growth in the country's production. ${ }^{98}$ The supply curve produced in the Rice University study is shown in Figure 11, with the vast majority of the gas economically producible at or below $\$ 6 / \mathrm{mmbtu}$, and it is interesting to note that in its most recent Annual Energy Outlook the EIA provided an long term estimate for US gas prices ranging from \$3.30/mmbtu in 2012 to $\$ 7.37 / \mathrm{mmbtu}$ in 2035, providing a slightly wider band than the Rice University Study.

\section{Figure 11: Cost of Supply Curve for US Shale Gas}

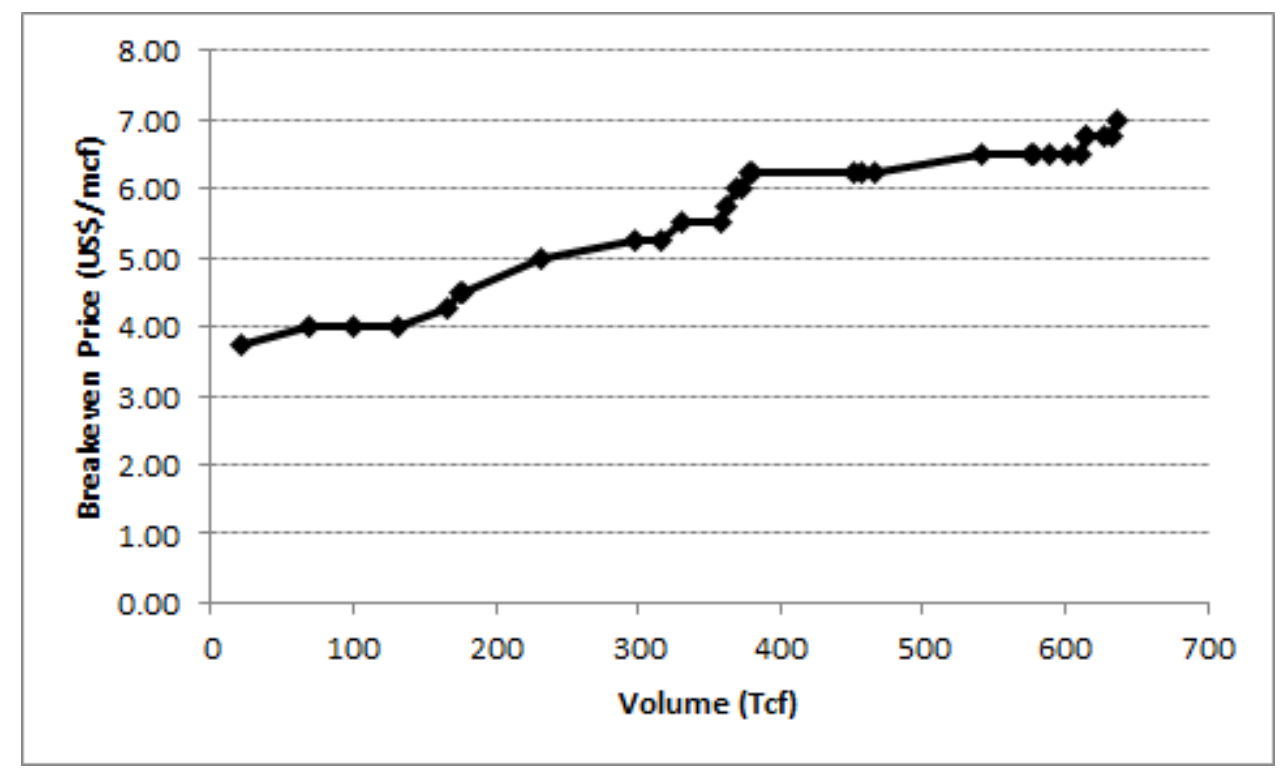

Source: Derived from data in Medlock, Jaffe, Hartley (2011)

Overall, then, it would appear that a reasonable assumption for the domestic cost of gas supply from the US would be in the range $\$ 4-7 / \mathrm{mmbtu}$, with a most likely outcome in the \$5$6 /$ mcf range to reflect the longer term economics of both conventional and unconventional production. This assumption therefore provides a basis upon which to calculate the cost of supply of potential US LNG exports to Asia and Europe, by adding the cost of liquefaction and transport to the cost of the gas. Data that Cheniere has provided about the contracts for gas supply from its Sabine Pass project suggest that a liquefaction cost of $\$ 3 / \mathrm{mmbtu}$ should

\footnotetext{
${ }^{97}$ Levi (2012)

${ }^{98}$ Medlock, Jaffe, Hartley (2011)
} 
be assumed, with an additional $\$ 3 / \mathrm{mmbtu}$ to be added for transport to Asia ${ }^{99}$ or $\$ 1.25 / \mathrm{mmbtu}$ for transport to Europe. Medlock (2012) suggests a slightly lower liquefaction cost of $\$ 2.92 / \mathrm{mmbtu}$ plus transport costs of $\$ 1.07 / \mathrm{mmbtu}$ to the UK and $\$ 2.15$ to Japan, but the analysis below assumes the Cheniere figures in order to remain conservative on the cost estimates and adds a fee of $\$ 0.35 / \mathrm{mmbtu}$ for regasification at the end market. Table 3 therefore shows a breakdown of the cost of supply to Asia and Europe at various Henry Hub price estimates, with the \$4-7 range highlighted in grey and the most likely \$5-6 range highlighted in yellow.

Table 3: The Delivered Cost of US LNG Exports to Europe and Asia (\$/mmbtu)

\begin{tabular}{|l|ccccccccc|}
\hline Henry Hub Price & $\mathbf{2 . 0}$ & $\mathbf{3 . 0}$ & $\mathbf{4 . 0}$ & $\mathbf{5 . 0}$ & $\mathbf{6 . 0}$ & $\mathbf{7 . 0}$ & $\mathbf{8 . 0}$ & $\mathbf{9 . 0}$ & $\mathbf{1 0 . 0}$ \\
Liquefaction & & & & & & & & & \\
& 3.0 & 3.0 & 3.0 & 3.0 & 3.0 & 3.0 & 3.0 & 3.0 & 3.0 \\
Transport to Europe & 1.3 & 1.3 & 1.3 & 1.3 & 1.3 & 1.3 & 1.3 & 1.3 & 1.3 \\
Transport to Asia & 3.0 & 3.0 & 3.0 & 3.0 & 3.0 & 3.0 & 3.0 & 3.0 & 3.0 \\
& & & & & & & & & \\
Regasification & 0.4 & 0.4 & 0.4 & 0.4 & 0.4 & 0.4 & 0.4 & 0.4 & 0.4 \\
& & & & & & & & & \\
Full Cost Europe & $\mathbf{6 . 6}$ & $\mathbf{7 . 6}$ & $\mathbf{8 . 6}$ & $\mathbf{9 . 6}$ & $\mathbf{1 0 . 6}$ & $\mathbf{1 1 . 6}$ & $\mathbf{1 2 . 6}$ & $\mathbf{1 3 . 6}$ & $\mathbf{1 4 . 6}$ \\
Full Cost Asia & $\mathbf{8 . 4}$ & $\mathbf{9 . 4}$ & $\mathbf{1 0 . 4}$ & $\mathbf{1 1 . 4}$ & $\mathbf{1 2 . 4}$ & $\mathbf{1 3 . 4}$ & $\mathbf{1 4 . 4}$ & $\mathbf{1 5 . 4}$ & $\mathbf{1 6 . 4}$ \\
\hline
\end{tabular}

Source: Author's calculations based on Cheniere Energy data

Note: Full Cost Asian figures assume use of the Panama Canal which will have been widened sufficiently to accept LNG vessels from 2014.

The initial conclusion from Table 3 is that it is clear why gas exports from North America based on Henry Hub prices would currently be attractive in both Europe and Asia. At the Henry Hub gas price in August 2012 of $\$ 2.83 / \mathrm{mmbtu}^{100}$ gas could arrive in Europe at $\$ 7.50 / \mathrm{mmbtu}$ compared to a spot price at the UK National Balancing Point (NBP) of $\$ 9.10 / \mathrm{mmbtu}$ and a current long-term oil-linked contract price for the first half of 2012 of approximately $\$ 400 / \mathrm{mcm}$ or $\$ 11.33 / \mathrm{mmbtu}$. As such there would appear to be a margin of $\$ 1.60-\$ 3.80 / m m b t u$ available for any exporter of US LNG who could access gas at Henry Hub prices.

\footnotetext{
${ }^{99}$ Note that the tariff for using the widened Panama Canal has not yet been established, and as a result any estimate of transport costs from the US Gulf Coast to Asia must be speculative at present. This $\$ 3 / \mathrm{mmbtu}$ estimate is based on data from Cheniere Energy, and likely assumes a tariff similar to that used in the Suez Canal. The Panama Authorities could decide to be more aggressive with their pricing, but it would also not be unreasonable to assume that they will establish a tariff to encourage trade for the long term rather than to necessarily maximise short-term profits.

${ }^{100}$ Price as of August 24 2012, as quoted on the Energy Intelligence Website at www.energyintel.com
} 
In Asia the commercial argument appears even more compelling, with a current theoretical landed cost of gas from the US of $\$ 9.23 / \mathrm{mmbtu}$ ( $\$ 2.83 / \mathrm{mmbtu}$ plus $\$ 6.40$ for liquefaction, transportation and regasification costs) being much lower than an average oil-linked contract price paid by Korea in July 2012 of $\$ 15.80 / \mathrm{mmbtu}$ and the $\$ 18.30 / \mathrm{mmbtu}$ price paid by Japan in the same month. ${ }^{101}$ The spot price for LNG during August 2012 had fallen as low as $\$ 12.90 / \mathrm{mmbtu},{ }^{102}$ but even at this relatively low level a margin of $\$ 3.70 / \mathrm{mmbtu}$ would be available for US exports, while the contract prices in Japan and Korea would offer margins in the range of $\$ 6.60-9.10 / \mathrm{mmbtu}$. As a result, it is clear that gas producers who can access LNG facilities on the west coast of Canada or the US, as well as those hoping to export LNG through a widened Panama canal from the Gulf Coast of the US, would be very keen to access the Asian export market as an alternative to domestic sales in North America.

However, as discussed above, in the longer term the cost of supply curve for US gas, combined with demand pressures in the US gas market, are likely to see US gas prices rise to a $\$ 4-7 / \mathrm{mmbtu}$ range, with $\$ 5-6 / \mathrm{mmbtu}$ the most likely outcome. At these higher prices the export of gas from the US appears rather less attractive, in particular to Europe. Indeed even at a US gas price of $\$ 5 / \mathrm{mmbtu}$ the landed cost in Europe would exceed the current spot price at NBP, while at $\$ 7 / \mathrm{mmbtu}$ it would exceed the average long-term (and largely oil-linked) contract price to Europe. As a result, it would appear that the likely impact of US exports on Europe in terms of volumes could be rather small, with a limited price impact relative to current levels.

${ }^{101}$ Interfax Gas Daily, 22 \& 23 Aug 2012, Japan and Korea LNG import price and volume data for July
${ }^{102}$ World Gas Intelligence, 15 Aug 2012, "Spot LNG: Prices fall in Asia, recover in Europe”, London 
Figure 12: The Cost of US LNG Exports Arriving in Europe (based on various Henry Hub (HH) prices)

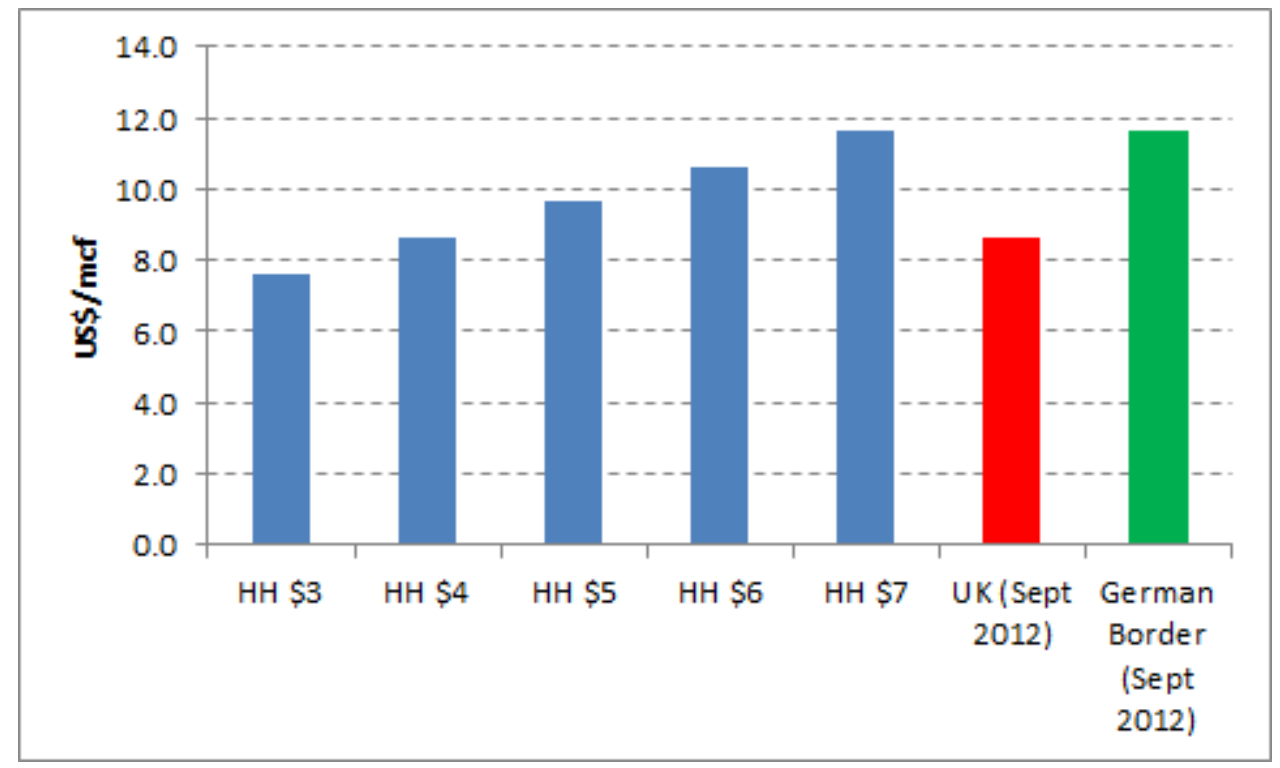

Source: Energy Intelligence Group Gas Price Database, Author's Calculations

The situation in Asia is rather more encouraging for US gas producers and LNG terminal owners. Even at the top end of the likely US gas price range $(\$ 7 / \mathrm{mmbtu})$ the landed cost of US gas exports in Asia would be approximately the same as the current LNG spot price in the region, and significantly below what is currently being paid under long-term contracts linked to the oil price. Indeed if one took a more generic approach, a standard long-term oil-linked contract with a $14.85 \%$ slope and a constant of 0.7 would equate to a gas price of approximately $\$ 17 / \mathrm{mmbtu}(\$ 600 / \mathrm{mcm}$ ) at the current oil price of c. $\$ 110 /$ barrel. Compared to this level the US gas price would need to increase to over $\$ 10 / \mathrm{mmbtu}$ before LNG exports would become uncompetitive, demonstrating that in Asia at least US gas based on Henry Hub prices can have a significant future impact.

The precise nature of that impact will depend upon the long-term elasticity of the gas supply curve into the Asian gas market. US LNG will slot into that supply curve at a point that is likely to be in the range $\$ 10-13 / \mathrm{mmbtu}$, depending upon the exact level of the Henry Hub price at the time, and as can be seen from the supply curve shown in Figure 12, this would place Sabine Pass very much in the middle of the cost range for LNG available to Asia over the next five to ten years (assuming a \$5.50/mmbtu Henry Hub price plus the 15\% premium being charged by Cheniere). 
Figure 13: Estimated Cost of LNG supply to Asia

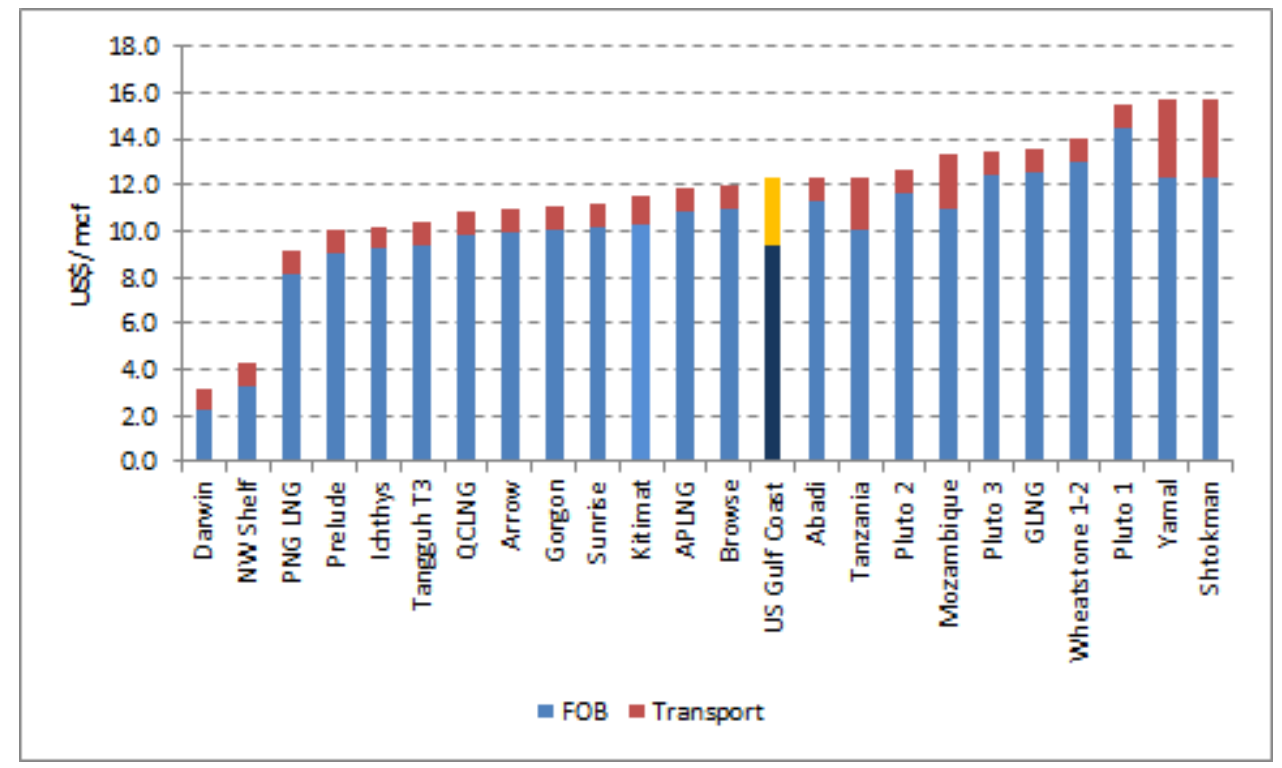

Source: Wood Mackenzie Consultants, Nexant World Gas Model, Credit Suisse First Boston, Company Data

An initial conclusion, therefore, would be that US gas exports could push out higher cost gas along the supply chain, leading to a reduction in the marginal cost of gas supply into Asia, although as can be seen from Figure 12 the difference in the cost of supply for many of the projects is not very high and so the price impact would not be very great. Canadian projects would also seem to be competitive in Asia (based on the Kitimat example above), although this is based on the less flexible economics of a greenfield project rather than the marketbased gas price used for the US Gulf Coast calculation. In addition, a number of further caveats need to be made. The first is that the short and long-term impacts are likely to be rather different, depending upon when North American gas can actually arrive in Asia for the first time. The consensus among industry commentators is that there will be an LNG supply shortage in the period 2012-2016, but that thereafter a surplus could emerge as many new projects potentially come on-stream. As a result, North American LNG arriving before 2016 would simply satisfy a supply shortage, with little likely price impact. However, after 2016, when the bulk of North American gas exports are scheduled, the impact on Asian spot gas prices could be more dramatic, even if a large share of demand has already been tied to longterm contracts.

A second, and very important, caveat is that the supply curve above does not include possible gas imports from Russia or potential domestic gas production from shale deposits in China. The latter in particular could be a game-changer in the Asian gas market, and could 
completely undermine any analysis of LNG or other gas import scenarios if it is successfully developed. Thirdly, the analysis also takes no account of the potential demand reaction to the possibility of lower prices in Asia. Demand in China in particular is already rising fast, and could be further encouraged by the arrival of cheap domestic or imported gas, with the implication that more of the supply options will be needed and that the equilibrium price could rise.

Finally, it needs to be acknowledged that many of the projects that will be supplying LNG to Asia over the next decade have already signed long-term contracts and therefore their volumes will be rather difficult to displace. As a result the impact of US LNG imports is most likely to be on spot prices rather than on the price of already contracted volumes, although it could reduce the sales from any projects with significant take-or-pay options enshrined in their agreements. However, it is also possible that existing contracts could be re-negotiated if the price differential between oil-linked and gas market-related prices remains wide at the time when the potential for North American exports is finally realised. A call for a paradigm shift in the LNG price formation mechanism has been made by Japan’s Trade Minister, ${ }^{103}$ and although the country's concerns over security of supply could mitigate against causing a dispute with producers the analogy from Europe of price re-negotiation via arbitration cannot be entirely discounted.

Overall, then, it would seem that although North American gas exports do appear attractive in Asia (and to an extent in Europe), the interaction of this new entrant with many other supply and demand drivers will determine the overall level of volumes that arrive from North America into export markets, while the likely price impact would not appear to be as dramatic as might be suggested by the current price disparities. Having said all this, US gas exports could still have an additional important role to play in changing the way consumers consider gas price formation across the globe, as the interaction of a market where gas-to-gas competition is prevalent with markets where oil-linked pricing remains very important is already causing disruption in price negotiations. One might further suggest that although Asia is the logical destination for North American LNG exports, the arrival of large volumes of North American LNG could displace some Middle East and African-sourced LNG towards Europe - further underlining the global impact which North American LNG might have in an increasingly 'connected' global system

${ }^{103}$ The Australian, 20 Sept 2012, "Shake up call on gas pricing threatens LNG” 
One way of considering this potential psychological impact of US LNG exports is to review the likely attitudes of the companies that will play a role in bringing the gas to market. Table 4 below defines six categories of market participants and attempts to identify their sales and pricing strategies and to consider their reaction if and when the US gas price increases over time. The six categories of participant are simple gas producers, gas producers who own liquefaction plants, consumers who own gas assets, third party owners of LNG terminals and liquefaction plants, portfolio buyers of gas at Henry Hub prices and consumer company buyers of gas at Henry Hub prices.

Table 4: Potential Reaction of Market Participants to US gas export possibilities

\begin{tabular}{|c|c|c|c|}
\hline & Sales Strategy & Price strategy & Reaction to rising US gas price \\
\hline $\begin{array}{l}\text { Indigenous owner of } \\
\text { gas assets }\end{array}$ & $\begin{array}{l}\text { Choice to sell into domestic } \\
\text { market or to buyer with } \\
\text { liquefaction capacity (e.g. } \\
\text { Cheniere) }\end{array}$ & $\begin{array}{l}\text { Take the highest price available - } \\
\text { Henry Hub or premium if offered by } \\
\text { LNG terminal owner/contractor }\end{array}$ & $\begin{array}{l}\text { More inclined to sell into US } \\
\text { domestic market, unless } \\
\text { premium continues to be offered } \\
\text { at LNG terminal }\end{array}$ \\
\hline $\begin{array}{l}\text { Indigenous owner of } \\
\text { gas assets who also } \\
\text { owns LNG terminal }\end{array}$ & $\begin{array}{l}\text { Aim for LT contract with Asian or } \\
\text { European consumer }\end{array}$ & $\begin{array}{l}\text { Aim for highest price available under } \\
\text { LT contract (currently oil-linked) }\end{array}$ & $\begin{array}{l}\text { Continue to sell under LT contract } \\
\text { terms }\end{array}$ \\
\hline $\begin{array}{l}\text { Consumer who owns } \\
\text { gas assets }\end{array}$ & $\begin{array}{l}\text { Sell gas to wholly-owned } \\
\text { subsidiary in home country }\end{array}$ & $\begin{array}{l}\text { Transfer pricing so relatively } \\
\text { indifferent }\end{array}$ & $\begin{array}{l}\text { Theoretically indifferent, but } \\
\text { could try to sell into US market if } \\
\text { domestic subsidiary can find } \\
\text { lower cost alternative supply }\end{array}$ \\
\hline $\begin{array}{l}\text { 3rd Party LNG } \\
\text { Terminal Owner }\end{array}$ & $\begin{array}{l}\text { Offer liquefaction of US } \\
\text { domestic gas to buyers in } \\
\text { markets where prices are higher }\end{array}$ & $\begin{array}{l}\text { Offer US gas at Henry Hub plus a } \\
\text { margin, in addition to covering costs of } \\
\text { liquefaction etc. }\end{array}$ & $\begin{array}{l}\text { US gas becomes less attractive in } \\
\text { export markets, so ensure that } \\
\text { liqufaction costs have been } \\
\text { covered in l-t capacity contracts }\end{array}$ \\
\hline $\begin{array}{l}\text { Portfolio buyer of gas } \\
\text { at HH prices }\end{array}$ & $\begin{array}{l}\text { Assimilate gas into sales } \\
\text { portfolio in order to maximise } \\
\text { arbitrage opportunities }\end{array}$ & $\begin{array}{l}\text { Relative price is key as profits driven } \\
\text { by arbitrage opportunities - incentive } \\
\text { to keep prices in Asia and Europe as } \\
\text { high as possible relative to N. America }\end{array}$ & $\begin{array}{l}\text { Sell gas back into US market if } \\
\text { arbitrage opportunities disappear }\end{array}$ \\
\hline $\begin{array}{l}\text { Consumer buying gas } \\
\text { at HH prices }\end{array}$ & $\begin{array}{l}\text { Bring gas into home country as } \\
\text { part of overall import portfolio, } \\
\text { with option to sell into } \\
\text { N.Amercian market if HH price } \\
\text { rises too high }\end{array}$ & $\begin{array}{l}\text { Price important relative to alternative } \\
\text { supplies - would price } \mathrm{N} \text {. American } \\
\text { exports at } \mathrm{HH} \text { plus cost of liquefaction } \\
\text { and transport }\end{array}$ & $\begin{array}{l}\text { Likely to have to accept gas at } \\
\text { higher prices as part of import } \\
\text { portfolio. May attempt to trade } \\
\text { back into the US market. }\end{array}$ \\
\hline
\end{tabular}

Source: Author's estimates

An indigenous gas producer has a clear choice to sell into the domestic North American market or to sell to the owner of a liquefaction plant at a Henry Hub related price plus a premium. The latter option would presumably be available until the price differential between the export market and the North American market became too small, at which point a domestic sale would become the obvious choice. More interesting is the indigenous producer 
who either owns, or has access to, liquefaction capacity. An example would be Shell at the planned LNG Canada project or ExxonMobil at the proposed Golden Pass project in Texas. These producers would again always have the option to sell into the domestic market, but in terms of sales to export markets would be incentivised to gain as high a price as possible rather than just to sell at Henry Hub plus a premium. Their initial inclination would be to sell on a long-term basis at oil-linked prices in order to extract the highest margin (i.e. to maintain the status quo) with the offer of a Henry Hub related price only being made if required to ensure the competitiveness of its gas. Similarly portfolio buyers of gas at US LNG terminals (for example BG at Sabine Pass) are similarly incentivised to maximise their own margins by attempting to buy at US prices and sell at oil-linked prices, again preferring the status quo if it can be maintained. In addition these portfolio buyers, who have the option to refuse to take the gas (or at least to sell it back into the domestic market) need to ensure that their sales price covers the cost of this option (in other words covers the cost of paying for liquefaction capacity even when it is not being used). Again this suggests that they would not be looking to sell at low Henry Hub-related prices unless absolutely necessary.

The third party owners of LNG terminals are somewhat indifferent to how ultimate prices are formed, as long as they can cover the costs of their LNG facilities and make a margin on the sale of Henry Hub gas. Cheniere is the prime example of this, with its contracts including a fixed fee to cover costs and a 15\% premium over Henry Hub prices for any gas purchased as LNG for export. The impact of these contracts is clearly to inflate the cost of the gas above the level it trades in the US market, but it does not have a direct impact on end consumer prices in export markets.

In contrast the consumers who own upstream assets and who either have access to or own liquefaction facilities, as well as those consumers who have contracted to buy gas from terminals at Henry Hub related prices, are incentivised to introduce the gas to the export market at as low a price as possible. PetroChina, for example, owns gas assets in Canada, is a partner in the proposed LNG Canada liquefaction facility and will therefore bring its own gas into the Chinese market. Although the whole process will involve internal transfer pricing and therefore will not provide a transparent pricing process, the ultimate impact will be that PetroChina will have (in theory) cheaper gas to add to its import portfolio to reduce its overall gas cost and improve its profitability. In a similar fashion, Japanese utilities Mitsubishi, Mitsui, Chubu Electric, Tokyo Gas, Sumitomo and Osaka Gas will hope to introduce gas at low Henry Hub prices into their domestic businesses in order to reduce their 
overall costs and enhance their competitive position. Again, although the effect may not be immediately obvious (i.e. an instant profit on the purchase and sale of the imported gas), the overall impact will be that access to lower gas prices has enhanced a company's profitability. Table 5 shows a number of firm agreements that have already been made for the export of gas from Canada and the US, although of course many of them rely on LNG facilities being granted non-FTA export status.

Table 5: Existing agreements for the export of North American gas

\begin{tabular}{|c|c|c|c|c|c|c|}
\hline Terminal & Buyers & Country & $\begin{array}{c}\text { Volume } \\
\text { Mt }\end{array}$ & $\begin{array}{l}\text { Term } \\
\text { Years }\end{array}$ & Start & Comment \\
\hline \multicolumn{7}{|l|}{ Canada } \\
\hline \multirow[t]{2}{*}{ Kitimat } & Kogas & South Korea & 2.0 & 20 & $2016 / 17$ & MoU signed in 2009 \\
\hline & Gas Natural & Portfolio & 1.6 & 20 & $2016 / 18$ & MoU signed in 2010 \\
\hline \multirow[t]{4}{*}{ LNG Canada } & Shell & Portfolio & 4.8 & na & 2019 & Partner with $40 \%$ interest in the project \\
\hline & Kogas & South Korea & 2.4 & na & 2019 & Partner with $20 \%$ interest in the project \\
\hline & Mitsubishi & Japan & 2.4 & na & 2019 & Partner with $20 \%$ interest in the project \\
\hline & PetroChina & China & 2.4 & na & 2019 & Partner with $20 \%$ interest in the project \\
\hline Total Canada & & & 15.6 & & & \\
\hline \multicolumn{7}{|l|}{ United States } \\
\hline \multirow[t]{4}{*}{ Sabine Pass } & BG & Portfolio & 6.0 & 20 & $2015-18$ & Confirmed contract \\
\hline & Gas Natural & Portfolio & 3.8 & 20 & $2015 / 16$ & Confirmed contract \\
\hline & Kogas & South Korea & 3.8 & 20 & $2017 / 18$ & Confirmed contract \\
\hline & Gail & India & 3.8 & 20 & $2017 / 18$ & Confirmed contract \\
\hline \multirow[t]{3}{*}{ Hackberry (Cameron LNG) } & Mitsubishi & Japan & 4.0 & 20 & 2017 & $\begin{array}{l}\text { Binding commitment to negotiate a } \\
\text { tolling agreement }\end{array}$ \\
\hline & Mitsui & Japan & 4.0 & 20 & 2017 & $\begin{array}{l}\text { Binding commitment to negotiate a } \\
\text { tolling agreement }\end{array}$ \\
\hline & GDF Suez & France & 4.0 & 20 & 2017 & $\begin{array}{l}\text { Binding commitment to negotiate a } \\
\text { tolling agreement }\end{array}$ \\
\hline \multirow[t]{2}{*}{ Freeport } & Osaka Gas & Japan & 2.2 & 20 & 2018 & $\begin{array}{l}\text { Tolling contract, gas to be sourced by } \\
\text { toller }\end{array}$ \\
\hline & Chubu Electric & Japan & 2.2 & 20 & 2018 & $\begin{array}{l}\text { Tolling contract, gas to be sourced by } \\
\text { toller }\end{array}$ \\
\hline \multirow[t]{2}{*}{ Cove Point } & Sumitomo & Japan & 1.15 & 20 & 2017 & $\begin{array}{l}\text { Tolling contract, gas to be sourced by } \\
\text { toller }\end{array}$ \\
\hline & Tokyo Gas & Japan & 1.15 & 20 & 2017 & $\begin{array}{l}\text { Tolling contract, gas to be sourced by } \\
\text { toller }\end{array}$ \\
\hline Total US & & & 36.2 & & & \\
\hline Total US \& Canada & & & 51.8 & & & \\
\hline
\end{tabular}

Source: Company press releases

Table 6 then shows a list of Asian owners of gas assets in North America who will be looking to bring their future supply into their own domestic market. As can be seen, a broad spread of 
Asian utilities has already gained exposure to the US and Canadian markets, and as a result will feel the impact of gas-on-gas price formation over the next few years either as a seller in the North American market or, if permitted, as an exporter of North American gas to Asia.

\section{Table 6: Asian owners of North American gas assets}

\begin{tabular}{|c|c|c|c|}
\hline Foreign Participant & $\begin{array}{l}\text { Asset } \\
\text { Location }\end{array}$ & Asset & Description \\
\hline PetroChina & Canada & Groundbirch Shale & $20 \%$ interest in shale gas assets in partnership with Shell \\
\hline \multirow[t]{2}{*}{ Sinopec } & Canada & Daylight Energy & $\begin{array}{l}\text { Acquisition of Canadian refiner with shale oil and gas assets in } \\
2011\end{array}$ \\
\hline & us & Devon Energy fields & $33 \%$ of five fields in Ohio, Michigan and Oklahoma \\
\hline \multirow[t]{3}{*}{ CNOOC } & us & Eagle Ford Shale & Purchase of $33 \%$ stake in Chesapeake assets for $\$ 1.1 \mathrm{bn}$ \\
\hline & & $\begin{array}{l}\text { Colorado \& Wyoming } \\
\text { shale }\end{array}$ & Purchase of $33 \%$ stake in oil-rich Chesapeake assets for $\$ 1.3 \mathrm{bn}$ \\
\hline & Canada & Nexen Energy & $\begin{array}{l}\text { Bid to purchase company with significant shale assets made in } \\
\text { July } 2012\end{array}$ \\
\hline \multirow[t]{2}{*}{ Sumitomo } & us & Marcellus Shale & $30 \%$ of assets owned by Rex Energy \\
\hline & Us & Barnett Shale (Texas) & $30 \%$ of oil and gas shale assets owned by Devon Energy \\
\hline \multirow[t]{2}{*}{ Mitsubishi } & Canada & Cutbank Ridge & $40 \%$ interest in Encana shale gas assets \\
\hline & Canada & Cordova Basin & $\begin{array}{l}30 \% \text { of JV with Penn West Exploration, Kogas and a Japanese } \\
\text { consortium }\end{array}$ \\
\hline \multirow[t]{2}{*}{ Mitsui } & us & Eagle Ford Shale & $12.5 \%$ interest in SM Energy gas assets in Texas \\
\hline & us & Marcellus Shale & $32.5 \%$ interest in Anadarko gas assets in Pennsylvania \\
\hline \multirow[t]{2}{*}{ Marubeni } & us & Eagle Ford Shale & $35 \%$ interest in Hunt Oil shale oil and gas assets \\
\hline & us & DJ Basin & $30 \%$ interest in Marathon shale oil assets in Wyoming \\
\hline Itochu & us & Samson Resources & $\begin{array}{l}25 \% \text { interest in US shale gas explorer and producer in partnership } \\
\text { with KKR }\end{array}$ \\
\hline Inpex & Canada & $\begin{array}{l}\text { Horn River, Cordova \& } \\
\text { Liard Basins }\end{array}$ & $\begin{array}{l}\text { JV with Nexen Energy to develop shale gas assets (Inpex to have } \\
40 \% \text { stake) }\end{array}$ \\
\hline Osaka Gas & us & Pearsall Shale & $35 \%$ of Cabot Oil \& Gas Corp assets in Texas \\
\hline KNOC & us & Eagle Ford Shale & $33 \%$ of Anadarko assets in Texas \\
\hline Kogas & Canada & Cordova Basin & $\begin{array}{l}5 \% \text { of JV with Penn West Exploration, Mitsubishi and a Japanese } \\
\text { consortium }\end{array}$ \\
\hline GAIL & us & Eagle Ford Shale & $20 \%$ interest in Carrizo assets in Texas \\
\hline Reliance & us & Marcellus & $40 \%$ interest in Atlas Energy gas assets \\
\hline Japan Consortium & Canada & Cordova Basin & $\begin{array}{l}\text { JOGMEC, Tokyo Gas, Chubu Electric and Osaka Gas each have } \\
3.75 \% \text { of project with Mitsubishi and PWE }\end{array}$ \\
\hline
\end{tabular}

Source: Company press releases 
As a result of this increased exposure to North American gas markets and price formation mechanisms, these Asian companies are likely to create the greatest impact using gas exports from the US and Canada. Their imports will arrive at Henry Hub-related prices (or at the cost of supply in the case of Canada) displacing higher cost supply, and will increasingly challenge the rationale for an oil-link in LNG contracts. The initial impact will most likely be on spot market prices, and as discussed above this impact will not be as dramatic as might be suggested by current price differentials because the interaction between the North American and Asian (and to an extent European) markets will see an equilibrium price reached in the long-term. However, the mere fact that this interaction is now set to occur and is being catalysed by consumers as well as producers suggests that a shift in the methodology for price formation in Asia could be catalysed and accelerated as North American gas starts to play a more global role. As a result, even if the volumes of North American gas that actually arrive in Asia and Europe are relatively small, their impact on prices and price formation across the globe could be significant and long-lasting. 


\section{Overall Conclusions}

The current price differential between North American gas prices and those in Europe and Asia is encouraging a broad energy industry initiative to create export opportunities for US and Canadian gas. Although only one US and one Canadian project currently have full export and construction approval, many others have applied for licences or been proposed, with a potential overall impact that could swamp the current global LNG market. Politicians in the US are very concerned about the impact that any exports could have on their domestic gas price and as a result on the US economy, with the consequence that an extensive review process is now underway which is unlikely to reach any definitive conclusion until 2013.

However, international trade theory suggests that the politicians should not be overly concerned, as the interaction between gas markets is likely to find an equilibrium price that will not be far removed from the price that would be needed to sustain US gas production in any case. In fact, at the $\$ 5-6 / \mathrm{mmbtu}$ price which most commentators believe will be needed to make US gas producers profitable, US gas exports to Europe immediately become less interesting. Indeed the most obvious influence of potential US exports based on this level of Henry Hub prices could be to provide a benchmark price of \$9.5.-10.5/mmbtu for Europe’s higher cost suppliers such as Russia, who would have a clear signal as to the price below which they would likely exclude a new rival source of supply or above which they would encourage its arrival in Europe. On the other hand physical exports to Asia look much more likely, even if the recent decline in LNG spot prices in the region is maintained, as North American gas exports would remain competitive with the oil-linked LNG contract price even if Henry Hub prices jumped to $\$ 8 / m m b t u$.

The implication, therefore, of North American gas exports to Asia is that higher cost sources of imports will be pushed down the supply chain, reducing the marginal cost of gas in the region. The situation could be complicated by a number of other factors, such as increased demand if prices stay low or the introduction of new indigenous production such as shale gas in China, which could certainly reduce the volumes of North American gas arriving in the Asian market. However, even if actual volumes are small, the impact of North American gas, and in particular that produced or purchased directly by consumers in Asia, may be as much psychological as physical. The introduction of gas at prices set by supply, demand and the cost of production, rather than based on a link to an alternative fuel, is likely to increase the focus on cost-of-supply-related rather than oil-related pricing. While it would probably be 
wrong to suggest that the oil link will disappear completely, given that oil is a competing fuel in some markets and has been used as the basis of contract negotiations for decades, nevertheless it would seem to be likely that, while the introduction of North American gas exports may not have as dramatic impact on global gas prices as expected it could significantly change the way in which prices are negotiated. 


\section{Bibliography}

BP (2005): BP Statistical Review of World Energy 2005,

http://www.bp.com/genericarticle.do?categoryId=2012968\&contentId=2001690

BP (2012): BP Statistical Review of World Energy 2012,

http://www.bp.com/extendedsectiongenericarticle.do?categoryId=9037129\&contentId=70746 06

Deloitte (2012): "Made in America: The economic impact of LNG exports from the United States”, Deloitte Center for Energy Solutions, June 2012, http://www.deloitte.com/view/en_US/us/Industries/oilgas/9f70dd1cc9324310VgnVCM1000001a56f00aRCRD.htm

EIA (2011) EIA, July 2011, "Review of Emerging Resources: US Shale Gas and Shale Oil Plays”, Washington, ftp://ftp.eia.doe.gov/natgas/usshaleplays.pdf

EIA (2012): “The Effect of Increased Natural Gas Exports on Domestic Energy Markets”, EIA, January 2012, http://www.eia.gov/analysis/requests/fe/pdf/fe_lng.pdf

Foss (2011): Foss, M. M., Dec 2011, “The Outlook for US Gas Prices in 2020: Henry Hub at $\$ 3$ or $\$ 10$ ?”, p. 35, Oxford Institute for Energy Studies, http://www.oxfordenergy.org/?s=The+Outlook+for+US+Gas+Prices+in+2020\%3A+Henry+ $\mathrm{Hub}+\mathrm{at}+\% 243+\mathrm{or}+\% 2410$

Levi (2012) "A Strategy of US Natural Gas Exports”, Michael Levi, Brookings Institute, June 2012, http://www.hamiltonproject.org/files/downloads_and_links/06_exports_levi.pdf.

Medlock (2012): Medlock III, K, B, “US LNG Exports: Truth and Consequence”, James A. Baker III Institute for Public Policy, Rice University, Texas, 10 Aug 2012, http://bakerinstitute.org/publications/US\%20LNG\%20Exports\%20\%20Truth\%20and\%20Consequence\%20Final_Aug12-1.pdf

Medlock, Jaffe, Hartley (2011) Medlock III, K.B., Jaffe, A.M., Hartley, P.R., July 2011, "Shale Gas and US National Security", James A. Baker III Institute for Public Policy, Rice University http://www.bakerinstitute.org/publications/EF-pub-DOEShaleGas-07192011.pdf

Nevins (2012): Nevins, P.J., 16 April 2012, “The USA as an LNG Exporter”, presentation to Flame Conference, Amsterdam

Rogers (2012): "The Impact of a Globalising Market on European Gas Supply and Pricing: The Importance of Asian Demand and North American Supply”, Oxford Institute for Energy Studies, NG 59, January 2012.

http://www.oxfordenergy.org/?s=The+Impact+of+a+Globalising+Market+on+European+Gas +Supply+and+Pricing\%3A+The+Importance+of+Asian+Demand+and+North+American+Su pply

Samuelson (1976): Samuelson, P., "Economics", Chapter 34 "International Trade and the Theory of Competitive Advantage”, pp.668-691, McGraw-Hill, New York, 1976. 
WEO (2011): The IEA World Energy Outlook 2011,

http://www.worldenergyoutlook.org/publications/weo-2011/ 